\title{
Paradoxen van deskundigen: Over de rol van experts in strafzaken [Paradoxes of experts: On the role of expert witnesses in criminal cases]
}

Citation for published version (APA):

van Koppen, P. J. (2004). Paradoxen van deskundigen: Over de rol van experts in strafzaken [Paradoxes of experts: On the role of expert witnesses in criminal cases]. Kluwer.

https://doi.org/10.26481/spe.20040604pk

Document status and date:

Published: 04/06/2004

DOI:

10.26481/spe.20040604pk

Document Version:

Publisher's PDF, also known as Version of record

Please check the document version of this publication:

- A submitted manuscript is the version of the article upon submission and before peer-review. There can be important differences between the submitted version and the official published version of record.

People interested in the research are advised to contact the author for the final version of the publication, or visit the DOI to the publisher's website.

- The final author version and the galley proof are versions of the publication after peer review.

- The final published version features the final layout of the paper including the volume, issue and page numbers.

Link to publication

\footnotetext{
General rights rights.

- You may freely distribute the URL identifying the publication in the public portal. please follow below link for the End User Agreement:

www.umlib.nl/taverne-license

Take down policy

If you believe that this document breaches copyright please contact us at:

repository@maastrichtuniversity.nl

providing details and we will investigate your claim.
}

Copyright and moral rights for the publications made accessible in the public portal are retained by the authors and/or other copyright owners and it is a condition of accessing publications that users recognise and abide by the legal requirements associated with these

- Users may download and print one copy of any publication from the public portal for the purpose of private study or research.

- You may not further distribute the material or use it for any profit-making activity or commercial gain

If the publication is distributed under the terms of Article 25fa of the Dutch Copyright Act, indicated by the "Taverne" license above, 


\section{Paradoxen van deskundigen}

\section{Over de rol van experts in strafzaken}

\section{P.J. van Koppen}

Rede, in verkorte vorm uitgesproken bij de aanvaarding van het ambt van hoogleraar Rechtspsychologie aan de Faculteit der Rechtsgeleerdheid van de Universiteit Maastricht, op vrijdag 4 juni 2004

\section{KLUWER}

Deventer

2004 
Ik dank Marijke Malsch, Henk Elffers, Hans Nijboer en Han Israëls voor commentaar op een eerdere versie van deze tekst.

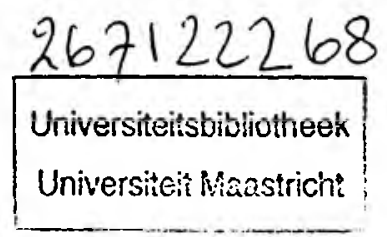

Omslagontwerp: A. Bimie Bno

\section{ISBN 9013018939}

(C) 2004. P.J. van Koppen

Alle rechten voorbehouden. Niets uit deze uitgave mag zonder voorafgaande toestemming van de uitgever worden verveelvoudigd of openbaar gemaakt.

Voor zover het maken van kopieën uit deze uitgave is toegestaan op grond van art. 16b Auteurswet 1912 jo. het Besluit van 20 juni 1974. Stb. 351, zoals gewljzigd bij Besluit van 23 aug. 1985. Stb. 471 , en art. 17 Auteurswet 1912, dient men de daarvoor wettelijk verschuldigde vergoedingen te voldoen aan de Stichting Reprorecht Hoofddorp (Postbus 3060, $2130 \mathrm{kB}$ ).

Hoewel aan de totstandkoming van deze de uiterste zorg is besteed, aanvaarden de auteur(s), redacteur(en) en uitgever(s) geen aansprakelijkheid voor eventuele fouten en onvolkomenheden. noch voor gevolgen hiervan.

Kluwer BV legt de gegevens van abonnees vast voor de uitvoering van de (abonnements)overeenkomst. De gegevens kunnen door Kluwer, of zorgvuldig geselecteerde derden, worden gebruikt om $u$ te informeren over relevante producten en diensten. Indien $u$ hier bezwaar tegen heeft. kunt u contact met ons opnemen.

Op alle uitgaven van Kluwer zijn de algemene leveringsvoorwaarden van toepassing. Deze kunt u lezen op www.kluwer.nl of opvragen via telefoonnummer 0570-673449. 
Paradoxen van deskundigen 

. . . . r

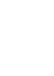

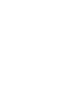

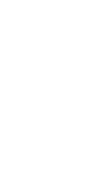
( (

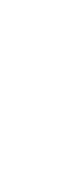

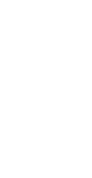

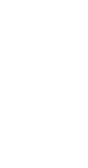

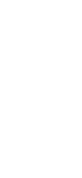

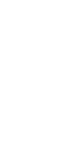
(2) ( (2)

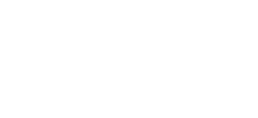
(2)

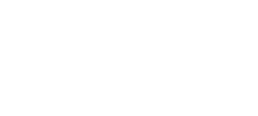

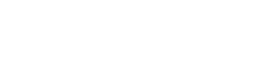


Getuigendeskundigen ${ }^{1}$ zijn er om de rechter te helpen bij zijn beslissing. ${ }^{2}$ Dat lijkt een open deur, maar ik zal laten zien dat die simpele constatering nogal wat min of meer paradoxale implicaties met zich meebrengt. En laat ik direct met de clou van mijn verhaal beginnen. Mijn conclusie zal zijn dat een deskundige in veel gevallen slechts de rechter behulpzaam kan zijn als hij ${ }^{3}$ op de stoel van de rechter gaat zitten. Maar dat vergt enige inleiding over het reilen en zeilen van de rechter en de deskundige.

\section{De rechter en de wetenschapper}

In strafzaken moet de rechter pro fundo twee oordelen geven. Hij moet beslissen of de verdachte het ten laste gelegde misdrijf heeft gepleegd en, als dat het geval is, wat er verder met hem moet gebeuren. Dat zijn praktische maatschappelijke oordelen.4 "De taak van de rechter is niet om vast te stellen wat de waarheid is, maar wat - gezien alle omstandigheden en de op het spel staande belangen - de relevante feiten zijn. [...] In het kader van de rechtszekerheid beëindigt de rechter de onzekerheid inzake de feiten, zodat

1. Mij is er herhaaldelijk door Hans Nijboer op gewezen dat deskundigen in deze een betere term is dan getuigendeskundige. De getuige moet immers de waarheid en niets dan de waarheld spreken, terwijl van de deskundige wordt verlangd dat hij zijn taak naar zijn geweten zal vervullen. De deskundige kan bij eedsbreuk daarom ook geen meineed plegen. Niettemin zal ik soms over getuigendeskundigen spreken, omdat het een bijzonder ingeburgerde term is.

2. Dat geldt niet alleen voor de zittingsrechter, maar ook in een eerder stadium in het vooronderzoek. Ik zal mij hier echter concentreren op de rol van getuigendeskundigen bij de finale beslissingen in een strafzaak.

3. Hoewel deskundigen soms vrouw zijn en onder de rechters zo langzamerhand evenveel vrouwen als mannen te vinden zijn - bij de jonge rechters zijn de vrouwen zelfs in de meerderheid - houd ik stug de mannelijke vorm vol.

4. Buruma (1996). 
partijen en de samenleving weer verder kunnen." 5 Bij die praktische maatschappelijke oordelen streeft de rechter naar zoveel mogelijk zekerheid voordat hij tot een beslissing komt.

In de meeste strafzaken is dat een relatief routinematig proces en levert dat geen bijzondere complicaties op. ${ }^{6}$ Een niet verwaarloosbaar deel van de strafzaken is echter ingewikkelder. In die zaken stellen zich voor de rechter beslissingsproblemen. Die liggen niet zelden buiten het juridische domein. Dan kan de rechter een deskundige inschakelen die zijn licht over zo'n probleem laat schijnen. De deskundige wordt overigens meestal al benaderd door de rechter-commissaris, de officier van Justitie of de verdediging. ${ }^{7}$ Iedereen om mij heen roept dat in toenemende mate in het strafproces deskundigen worden ingeschakeld. Dat zal wel zo zijn, maar ik heb hierover geen empirische gegevens kunnen vinden.

De rechter legt een probleem voor aan een deskundige, veelal een wetenschapper, in de verwachting dat die een 'objectief oordeel zou kunnen' leveren dat leidt tot een waar feit dan wel een vaststaande wetmatigheid. Dat is paradoxaal, omdat de rechter voor zekerheid helemaal niet op de wetenschap kan varen. Ja, vroeger streefde men in de wetenschap naar zekerheid. Dat standpunt is echter al lang verlaten, niet in de laatste plaats door de invloed van het kentheoretische werk van Karl Popper. ${ }^{8}$ Er zijn slechts hypotheses en theorieën die door onderzoek al dan niet ondersteund dan wel gefalsifieerd worden. Een hypothese die is ondersteund in empirisch onderzoek is slechts voorlopig waar en blijft onderwerp vormen van discus-

5. Zo omschrijft Hildebrandt (2004), p. 191, het.

6. Een redelijke schatting is dat dit opgaat voor zo'n $88 \%$ van de strafzaken die voor de meervoudige kamer van de rechtbank komen. Zie Crombag, Van Koppen \& Wagenaar (1994), pp. 20 e.v.

7. Corstens (2002), p. 139, merkt op dat rapporten op initiatief van het openbaar ministerie en de verdediging buiten de wettelijke regeling tot stand zijn gekomen en om die reden niet voor het bewijs geaccepteerd zouden moeten worden. De Hoge Raad besliste echter anders in HR 2 december 1935, NJ 1936, 136 m.nt. T.

8. Waarbij zijn meest invloedrijke werk is Popper (1934). In Nederland is in die zin van grote invloed geweest het werk van A.D. de Groot (1961). 
sie. Op logische gronden kan een hypothese namelijk slechts worden verworpen, maar nooit worden bewezen. Wat wetenschappelijke feiten zijn, zijn in feite interpretaties van waarnemingen waarover de participanten in het veld het voorlopig eens lijken te $z$ ijn. ${ }^{9}$ De voortgaande discussie aan de hand van empirisch onderzoek en logische argumenten maakt het wetenschapsbedrijf juist zo leuk, ${ }^{10}$ bijna net zo leuk als zeilen.

"In het recht daarentegen vraagt de rechtszekerheid dat op grond van de beschikbare informatie een definitief oordeel wordt geveld." 11 Het wetenschapsbedrijf is er dus niet op gericht het soort zekerheid te produceren waar de rechter om vraagt. ${ }^{12}$ Een typisch voorbeeld is het experiment in de psychologie. Wij willen bijvoorbeeld weten of seksueel misbruikte kinderen anders spelen met anatomisch correcte poppen dan niet-seksueel misbruikte kinderen. ${ }^{13}$ En inderdaad: tussen de experimentele groep, de seksueel misbruikte kinderen, en de controlegroep, de niet-seksueel misbruikte kinderen, vinden wij een verschil. De kinderen in de experimentele groep doen gemiddeld meer seksueel getinte spelletjes met de poppen en dat verschil tussen de twee gemiddelden is dusdanig groot dat wij het verschil niet meer kunnen toeschrijven aan toeval. Wij noemen het verschil dan significant en trekken de conclusie dat seksueel misbruik een ander spel met de poppen veroorzaakt. Dat is een keurige conclusie binnen het psychologische domein.

Kan de rechter daarop varen? Nou, nee, en wel om een aantal redenen.

9. Zie voor die sociale constructie van het wetenschapsbedrijf Hofstee (1980).

10. Een dergelijke manier van hypothetisch-deductlef redeneren komt men wel tegen in het opsporingsonderzoek. Daarin leldt men uit een veelbelovende hypothese - bijvoorbeeld wie de dader is - via deductie af welke fenomenen dan zouden moeten optreden, zoals welk bewijs men dan zou moeten vinden. Met dat bewijs wordt die hypothese vervolgens weer getoetst. Zie De Poot, Bokhorst, Van Koppen \& Muller (2004). Broeders (2003), hoofdstuk 4, stelt datzelfde voor voor de forensisch deskundige.

11. Hildebrandt (2004).

12. Overigens is Nijboer van mening dat dit type problemen eveneens geldt voor het strafrecht. Zie Nijboer (1982), Nijboer (2000), hoofdstuk 1.1-1.3, en Nijboer (2003).

13. Zie bijvoorbeeld White, Strom, Santilli \& Halpin (1986) en Cohn (1991). 
Ten eerste is het verschil tussen het spel van misbruikte kinderen en nietmisbruikte kinderen weliswaar significant, maar dat betekent nog niet dat het verschil ook groot is. Ten tweede is de rechter niet geïnteresseerd in gemiddelde verschillen tussen groepen kinderen, maar in iets geheel anders. Hij wil met zoveel mogelijk zekerheid weten of dit specifieke kind seksueel is misbruikt. En dat is een vraag van een geheel andere orde. Niet: veroorzaakt seksueel misbruik seksueel spel met poppen, maar: kan uit seksueel spel met poppen afgeleid worden dat het kind seksueel is misbruikt. ${ }^{14}$ Ook op dat punt faalt de poppenmethode jammerlijk, al was het alleen maar doordat niet-misbruikte kinderen nieuwsgierig zijn en daardoor ook seksuele spelletjes spelen met die poppen. Dat zag de Hoge Raad gelukkig ook in. ${ }^{15}$ zodat wij de poppen in het forensische vaarwater vrijwel niet meer tegenkomen.

Ongemerkt ben ik van de ene functie van de deskundige - namelijk inzicht geven in de stand van de wetenschap op een bepaald gebied - terecht gekomen op de tweede functie, namelijk wetenschappelijke kennis toepassen op de concrete zaak. ${ }^{16}$ Dat laatste is natuurlijk in veel meer zaken nuttig voor de rechter. Popper was van oordeel dat zijn falsificatieprincipe - dus dat hypotheses nooit bewezen, doch slechts gefalsificeerd kunnen worden slecht geldt voor algemene uitspraken. Het zou niet gelden voor specifieke uitspraken. Dat klopt, zolang het gaat om eenvoudige en ondubbelzinnig vast te stellen fenomenen, zoals de lengte van een persoon of diens haarkleur. Maar zodra het om iets ingewikkelders gaat, wordt men snel met dezelfde problemen geconfronteerd. In die categorie valt zeker de vraag of dit kind seksueel is misbruikt.

Een veel betere methode dan de anatomisch correcte poppen is de Criteria Based Content Analysis, de CBCA. ${ }^{17}$ Dat is een methode waarmee aan de hand van 19 criteria beoordeeld wordt of de verklaring van een kind geloof-

14. Zie over dit probleem ook Rassin \& Merckelbach (1999).

15. HR 28 februari 1989, NJ 1989, 748 (Anatomisch Correcte Poppen).

16 Zie de taxonomie van Gross \& Mnookin (2003).

17 Zie Soppe (1997) en Rassin \& Van Koppen (2002). 
waardig is. Op die methode is in de literatuur veel kritiek geleverd. ${ }^{18} \mathrm{De}$ $\mathrm{CBCA}$ is in het psychologische discours echter eveneens een valide methode. Het is ook een goede methode om aan de rechter een analyse te presenteren van een verhoor van een kind. Maar opnieuw is deze methode onvoldoende sterk om op grond daarvan aan de rechter een conclusie te leveren over het waarheidsgehalte van de verklaring van het kind. Ook over de CBCA heeft de Hoge Raad inmiddels een arrest gewezen in een zaak waarin de ene deskundige de CBCA toepaste en een andere deskundige op verzoek van de verdediging een kritisch rapport schreef. Die kritiek werd in deze zaak verwoord in een verweer van de verdediging dat gebaseerd was op een rapport van de tweede deskundige. De Hoge Raad besloot dat "het Hof nader had moeten motiveren waarom het zich bij genoemde beslissing heeft gebaseerd op de eindconclusie van het rapport van [de eerste deskundige]."19

Op deze en soortgelijke manieren wordt de rechter nog wel eens geconfronteerd met verschillende deskundigen die verschillende opvattingen hebben. Een extreem voorbeeld wordt gegeven door Fisher en Whiting. ${ }^{20}$ Volgens moeder vertelt op een gegeven moment een driejarig jongetje dat zijn vader - en ex-man van moeder - hem onzedelijk betast zou hebben. Oma en tante waren bij de mededeling van het jongetje en bevestigen het verhaal van moeder. In de loop van de tijd gaven verschillende deskundigen hun oordeel over de zaak. Zij gebruikten alle vier verschillende methodes. Eén deskundige meldde dat zij niet tot enige conclusie had kunnen komen over het waarheidsgehalte van de verklaring van het jongetje. Een tweede deskundige wist te vertellen dat het jongetje het slachtoffer was geworden van oraal genitaal contact en masturbatie. De derde zei dat het verhaal bij het jongetje geïmplanteerd was en adviseerde het jongetje tegen zijn moeder te beschermen. De vierde meende dat het zoontje niet het slachtoffer van seksueel misbruik door de vader kon zijn, omdat de vader niet voldeed aan het

18 Zie bijvoorbeeld Horowitz, Lamb, Esplin, Boychuk, Krispin \& Reiter-Lavery (1997), Lamb \& Sternberg (1998). Ruby \& Brigham (1997) en Rassin \& Van Koppen (2002).

19 HR 30 maart 1999, NJ 1999, 451, m.nt. 't H. (CBCA).

20 Fisher \& Whiting (1998), die het weer ontleenden aan Brooks \& Milcham (1991). 
profiel van een pedofiel. De rechter kan met zo'n palet aan uiteenlopende oordelen geen land bezeilen.

\section{De rechter als wetenschapper}

Met het CBCA-arrest geeft de Hoge Raad in feite de paradoxale opdracht aan de rechter om in dit soort situaties te beslissen - en te beargumenteren welke deskundige gelijk heeft. ${ }^{21}$ Soms hebben deskundigen verschillende opvattingen omdat de ene deskundige recht door zee is en de ander een charlatan. Niet zelden zijn de verschillen echter inherent aan het wetenschapsbedrijf en zijn zij daarvoor essentieel. Verschillen van mening zorgen voor de voortgaande discussie. De rechter vraagt deskundigen om hem zekerheid te bieden, hij wordt vervolgens geconfronteerd met verschillende opvattingen in de wetenschappelijke discussie en moet dan in dat discours een standpunt innemen. Maar de deskundigen werden juist geëngageerd omdat de rechter van het betreffende gebied geen verstand heeft. De rechter is dus principieel niet in staat de afweging te maken waartoe de Hoge Raad hem opdracht geeft. 22

Niettemin draagt de rechter het droeve lot dat hij moet kiezen en hij heeft daarvoor geen directe mogelijkheden tot toetsing. Toetsing moet dus op indirecte manier gebeuren. In de Verenigde Staten heeft daartoe lange tijd het Frye-criterium gegolden. ${ }^{23}$

"Just when a scientific principle or discovery crosses the line between experimental and the demonstrable stages is difficult to define. [...] [W] hile the courts go a long way in admitting expert testi-

21 Zie voor een vergelijkbare Amerikaanse zaak New Jersey v. Cavallo, 88 N.J. 508, 443 A.2d. 1020 (1982), waarin de rechter de opdracht krijgt bij twijfel over een verklaring van een deskundige het aan andere deskundigen te vragen, of geschillen tussen deskundigen op te lossen door wetenschappelijke of juridische geschriften te raadplegen of met juridische precedenten. Dat lost natuurlijk niks op.

22 Zie hierover ook Nijboer (2004a).

23 Frye v. United States 293 F. 1013 (D.C. Cir., 1923), cursivering toegevoegd. 
mony deduced from a well-recognized scientific principle or discovery, the thing from which the deduction is made must be sufficiently established to have general acceptance in the particular field in which it belongs."

Dat lijkt een oplossing te geven, maar doet dat niet. General acceptance is dat niet, omdat veel onzin bijvoorbeeld in een veld als astrologie algemeen geaccepteerd is. Dus moet de rechter op een andere manier de kwaliteit van de deskundige en diens verhaal toetsen. ${ }^{24}$

Het Amerikaanse Hooggerechtshof gaf daarvoor een handreiking in de Daubert-beslissing. ${ }^{25}$ In die beslissing noemt het vier criteria. Ten eerste kan de rechter overwegen of de wetenschappelijk kennis getoetst kan worden of getoetst is. Ten tweede kan de validiteit van de methode beoordeeld worden doordat de theorie of de techniek "has been subjected to peer review or publication". Ten derde kan de rechter de bekende of potentiële foutenmarge van de methode in overweging nemen. En ten vierde zou de rechter kunnen letten op het bekende Frye-criterium, de general acceptance. Over deze beslissing is in de Verenigde Staten inmiddels onvoorstelbaar veel geschreven. ${ }^{26}$ In de literatuur gaat men meestal de mist in op het punt dat het lijstje van vier regels door het Supreme Court wordt gepresenteerd als een limitatief lijstje. Dat is het niet. Vlak daarvoor schrijft het Supreme Court namelijk:

"Faced with a proffer of expert scientific testimony, then, the trial judge must determine at the outset $[\ldots]$ whether the expert is proposing to testify to (1) scientific knowledge that (2) will assist the trier of fact to understand or determine a fact in issue. This entails a preliminary assessment of whether the reasoning or methodology underlying

24 Zle ook Van Kampen (1998).

25 Daubert v. Merrell Dow Pharmaceuticals Inc., 509 U.S. 579, 113 S.Ct. 2795 (1993).

26 Op 11 mei 2004 vond ik 553 artikelen in wetenschappelijke tijdschriften over dit arrest. Zie bijvoorbeeld Saks (1994), Faigman (1995), Saks (2000) en Penrod, Fulero \& Cutler (1995). Ook in het Nederlands: Broeders (2002). 
the testimony is scientifically valid and of whether that reasoning or methodology properly can be applied to the facts in issue. We are confident that federal judges possess the capacity to undertake this review. Many factors will bear on the inquiry, and we do not presume to set out a definitive checklist or test. But some general observations are appropriate."

Het Supreme Court geeft in feite de Amerikaanse rechter de opdracht om zelf deskundigenrapporten te beoordelen en acht hem daartoe ook in staat. In die zin lijkt de Daubert-beslissing sterk op de richtlijnen die de Hoge Raad gaf in het CBCA-arrest, maar ook in het een jaar eerder gewezen Schoenmakerarrest. ${ }^{27}$ Dat laatste arrest betrof de Helmondse carnavalsmoord. De politie had in het onderzoek naar die moord voor het vergelijken van schoenzoolsporen gebruik gemaakt van de diensten van een orthopedische schoenmaker. Een wat curieuze beslissing van de politie, want een orthopedisch schoenmaker lijkt niet direct deskundig op het gebied van schoensporen en bovendien heeft de politie op dit gebied zelf deskundigen in huis, namelijk bij de Nationale Recherche Informatiedienst (NRI) in Zoetermeer. De verdediging had dan ook bezwaar gemaakt tegen gebruik van de verklaring van de schoenmaker. De Hoge Raad besliste dat het Hof, als het van de verklaring van de schoenmaker gebruik maakt als bewijsmiddel in het arrest, wel wat mag uitleggen, opnieuw overigens alleen als de verdediging expliciet en gemotiveerd bezwaren tegen de verklaring van de deskundige naar voren heeft gebracht. In dat geval moet de rechter uitleggen: (1) dat de deskundige deskundig is op het gebied van schoensporen. Als dat het geval is (2) welke methode de deskundige heeft gebruikt, (3) waarom de deskundige deze methode betrouwbaar genoeg acht en (4) in welke mate de deskundige in staat is deze methode competent toe te passen.

Zijn dit soort eisen nu nodig? Ja, en nog veel meer eisen ook. ${ }^{28}$ Die zijn niet nodig omdat getuigendeskundigen niet hun best doen of de rechter in

27 HR 27 Januart 1998, NJ 1998, 404 (Schoenmaker blijf bij je leest); m.nt. JR.

28 Zle Van Koppen (2000), Van Koppen \& Saks (2003) en Van Koppen \& Penrod (2003). 
de boot nemen. Zij zijn nodig omdat getuigendeskundigen vaak hun eigen rol in het strafproces niet goed begrijpen, methodes toepassen die ongeschikt zijn voor de forensische context, hun bevindingen te stellig presenteren of gewoon door rechters, advocaten en officieren van Justitie verkeerd worden begrepen.

Die eisen lossen de paradox voor de rechter echter niet op. Crombag stelde in zijn afscheidsrede op deze zelfde plaats dat het dringend gewenst is dat een onderdeel van de juridische opleiding wordt de "methodologie en zeden en gewoonten van de empirische wetenschappen, inclusief elementair begrip van de kwantitatieve analyse." 29 Dat zou inderdaad wel een beetje helpen. Crombag realiseert zich echter niet hoe divers de deskundigen zijn die voor de rechter optreden. Neem bijvoorbeeld alle specialismen bij het Nederlands Forensisch Instituut (NFI) te Rijswijk, ${ }^{30}$ maar de rechter ziet bijvoorbeeld ook accountants, meteorologen, telecommunicatiemensen, psychologen, psychiaters, neurologen en andere artsen voorbijkomen. En dan zijn er ook nog allerlei subdisciplines, met elk weer hun eigen eigenaardigheden. Mijn vakgenoten spreken tegen de rechter bijvoorbeeld over onderwerpen als waarnemingen door getuigen, ${ }^{31}$ de kwaliteit van verhoren, ${ }^{32}$ de waarde van bekentenissen, ${ }^{33}$ herkenningsprocedures, ${ }^{34}$ de geursorteerproef door honden, ${ }^{35}$ maar ook de beste behandeling voor de verdachte en diens toekomstige gevaarlijkheid. ${ }^{36}$ Zo kunnen wij de hele juridische opleiding vullen met basiscursussen van het een of ander.

Hoge eisen aan deskundigen lossen de paradox ook niet geheel op, maar maken het voor de rechter iets eenvoudiger om een beslissing te nemen over

Crombag (2000).

30 Broeders (2000) en Broeders (2003).

31 Wolters (2002).

32 Vrij (2002) en Gudjonsson (2003).

33 Gudjonsson (2003) en Van Koppen (1998).

34 Van Koppen \& Wagenaar (2002).

35 Schoon \& Van Koppen (2002).

36 De Ruiter (2000) en De Ruiter (2004). 
het deskundigenbewijs. Daarbij helpt een open discussie. ${ }^{37}$ Zo werd ik een paar jaar geleden opgeroepen voor het Hof Den Bosch in een zaak waarin een geursorteerproef aan de orde was. Enige weken voor de geplande zitting belde éen van de raadsheren mij op met de vraag wat hij het beste kon lezen ter voorbereiding van de zitting. Die open houding leverde in ieder geval in deze zaak een bijzonder zinvolle discussie op ter terechtzitting.

Deskundigen kunnen ook wel wat helderder zijn. Laat ik eerlijkheidshalve een voorbeeld geven waarin ik zelf de mist in ging. Bij een moord in 1998 op de Markt in Valkenswaard werd een man in zijn auto om het leven gebracht. Het gebeurde op een zonnige dag vlak voor vol zittende terrassen. Er waren nogal wat getuigen die uiteenlopende beschrijvingen gaven van het hoofddeksel van de dader. Bij de verdachte werd in diens auto een petje gevonden. Dat petje werd aan de getuigen getoond, waarvan drie zeiden het te herkennen, ondanks dat de getuigen behoorlijk uiteenlopende beschrijvingen hadden gegeven. Ik schreef in mijn rapport: "Bij de herkenningen van objecten is in de onderhavige zaak de verkeerde procedure gebruikt. De diagnostische waarde van die herkenningen is daarom gering." Dat was nogal genuanceerd; te genuanceerd, want er had gewoon moeten staan dat deze procedure volstrekt ondeugdelijk was, zeker gezien de uiteenlopende beschrijvingen en dat de resultaten dus nietszeggend waren.

De verdachte ging in cassatie met de klacht dat het petje-bewijs niet gebruikt had mogen worden. ${ }^{38}$ De Hoge Raad floot het Hof niet terug. De Hoge Raad sloot zich daarmee aan bij de advocaat-generaal die in zijn conclusie had geschreven: "In de opmerkingen van de deskundige ligt niet besloten dat de wijze van tonen van de pet aan de getuigen een zo dubieuze onderzoeksmethode vormde dat aan de uitkomst ervan geen enkele betekenis kan worden gehecht." Ja, zo'n zin is een helder baken in zee. Wat de advocaatgeneraal bedoelt, is dat ik niet gezegd had dat de herkenningen van het petje geen enkele waarde hadden. Nou, dat bedoelde ik wel, maar heb dat gewoon te genuanceerd opgeschreven en daarmee de rechter misleid. 


\section{Van wetenschap naar techniek}

$\mathrm{Nu}$ wil het wel eens gebeuren dat binnen een wetenschapsgebied over een bepaald onderwerp dermate grote consensus is ontstaan, dat de discussie daarover niet of nauwelijks meer wordt gevoerd. Dan is, in Frye-termen, sprake van general acceptance in the relevant field. Daarmee is dat gebied ook geworden van wetenschap - de voortdurende discussie - tot techniek. In het forensische veld lijkt dat bijvoorbeeld op te gaan voor vingerafdrukken, voor DNA-profielen, maar ook voor psychiatrisch en psychologisch onderzoek naar de toerekeningsvatbaarheid van de verdachte. Zo'n gebied is een rustig vaarwater voor de rechter. Hij kan op de resultaten van het onderzoek afgaan zonder zich te hoeven bekommeren om allerlei wetenschappelijke discussies.

Voor die gebieden lijken de richtlijnen van het Schoenmakerarrest ook adequaat. Als de deskundige deskundig is, zijn werk naar behoren heeft gedaan en dat ook kan uitleggen, kan de rechter zijn oordeel veilig verankeren in het rapport van de deskundige. Maar is dat terecht? Zouden rechters zich niet tevens moeten afvragen waarom op dat gebied geen discussie meer is of lijkt te zijn? Daartoe blijkt alle reden te zijn op de drie genoemde gebieden.

Het gaat misschien te ver om met Risinger en Saks te oordelen dat het forensische onderzoek een huis is zonder enig fundament. ${ }^{39}$ Maar het is wel duidelijk dat de forensisch onderzoekers een sfeer om zich heen hebben gecreëerd die suggereert dat zij foutloos zijn, terwijl veel forensisch onderzoek subjectief is, op vele punten nog deugdelijk empirisch onderzoek ontbeert en resultaten diverse interpretaties toelaten.

\section{Vingerafdrukuergelijking}

Het meest pregnante voorbeeld is de dactyloscopie. Aan het einde van de negentiende eeuw en het begin van de twintigste eeuw werden vingerafdrukken vrijwel overal ter wereld geruisloos als bewijsmiddel geaccep- 
teerd. ${ }^{40}$ Dactyloscopisten werden zelden of nooit kritisch bevraagd. Dat heeft hen de mogelijkheid gegeven elke match te presenteren in absolute termen waarover geen twijfel mogelijk is. ${ }^{41}$ Als in Nederland een vingerafdruk op 12 of meer punten overeenkomt met die van de verdachte concludeert de dactyloscopist dat hij met absolute zekerheid door de verdachte is gemaakt; als er 11 of minder punten van overeenkomst zijn, is de vingerafdruk onvoldoende en wordt hij als onbruikbaar beschouwd. ${ }^{42}$ De simpele vraag aan vingerafdrukkenexperts: "Hoe groot is de kans dat twee vingerafdrukken matchen, terwijl zij afkomstig zijn van twee verschillende personen" wordt hun nooit gesteld. Althans, tot voor kort, want sinds enige jaren worden in de Verenigde Staten wel degelijk vragen gesteld bij de toelaatbaarheid van vingerafdrukken voor het bewijs, namelijk vanaf 1999.43 De regels van de International Association for Identification verbieden haar leden echter om die vraag op te werpen: het is professional misconduct voor een dactyloscopist om in termen van waarschijnlijkheid over een match te spreken. ${ }^{44}$

Het absolute oordeel is gebaseerd op de onbewezen stelling dat de natuur zich niet herhaalt en dus dat elke vingerafdruk uniek is. Of die stelling waar is, weten wij natuurlijk niet en dat kan ook niet empirisch getoetst worden.

40 Zie voor een historisch overzicht Kingston \& Kirk (1965).

41 Hoe dat zo gekomen is wordt beschreven door Mnookin (2001) en Kingston \& Kirk (1965).

42 Kingsion \& Kurk (1965), p. 85. Niet dat in het verleden niet getracht is om over vingerafdrukken in termen van waarschijnlijkheden te spreken. Dat deed bijvoorbeeld Galton (1892), maar na hem ook anderen. Zie voor een overzicht Champod (1995) en Champod. Lennard \& Margot (1993).

43 Als eerste in U.S. v. Mitchell, No. 96-407 (E.D. Pa. 1999). De argumenten zijn in het algemeen drieledig tegen vingerafdrukken: (1) Er zijn geen objectieve en bewezen standaarden om te beoordelen of twee vingerafdrukken matchen; (2) De foutenmarge van het vergelijken van vingerafdrukken is onvoldoende onderzocht; en (3) $\mathrm{Er}$ bestaat geen statistisch materiaal op grond waarvan kan worden beslist hoe groot de kans is dat twee verschillende personen afdrukken zouden kunnen hebben met een bepaald aantal overeenkomende kenmerken. Zle Mnookin (2001), p. 58. Daaraan kan worden toegevoegd dat het bepalen van een match noodzakelijkerwijs een subjectief oordeel is. Zie ook Epstein (2002).

44 Mnookin (2001), pp. 29-30. 
Maar men zou wel daarbij in de buurt kunnen komen door een grote verzameling vingerafdrukken van verschillende personen met elkaar te vergelijken. Als men dan geen vingerafdrukken van verschillende mensen vindt die niet van elkaar kunnen worden onderscheiden, dan kan het bestaan van twee identieke afdrukken van verschillende personen weliswaar niet geheel worden uitgesloten, maar men zou de kans daarop klein kunnen oordelen. Die kans kan zo gering zijn, dat zij in de praktijk verwaarloosd mag worden. Maar ook dit in principe uitvoerbare, maar zeer bewerkelijke onderzoek is eigenlijk nooit gedaan. ${ }^{45} \mathrm{Wij}$ weten dat vingerafdrukken sterk bewijs van identiteit zijn, louter en alleen omdat dactyloscopisten dat zeggen. En toch wordt hun oordeel vrijwel altijd zonder meer geaccepteerd door de rechter.

$\mathrm{Nu}$ worden bij vingerafdrukken tegenwoordig computers gebruikt. In $\mathrm{Ne}-$ derland is dat HAVANK, in gebruik bij het NRI in Zoetermeer. Die computer maakt echter niet de vergelijking, maar maakt voor de vingerafdrukkenexpert een voorselectie. Of er sprake is van een match wordt door een persoon en op het oog besloten. Dat is een subjectief oordeel dat, hoe goed opgeleid de mensen ook zijn, vatbaar is voor fouten. 46

De subjectiviteit van het oordeel doet nog op een andere manier afbreuk aan het absolute van vingerafdrukvergelijking. ${ }^{47}$ De afdruk van de plaats delict en de van de verdachte afgenomen vingerafdruk zijn niet altijd van goede kwaliteit. Daardoor kunnen de te vergelijken vingerafdrukken van dezelfde persoon niettemin verschillen. ${ }^{48}$ De deskundige moet kiezen: gaat het om afdrukken van verschillende personen of gaat het om wat genoemd

45. Voor meer uitleg zie Van Koppen \& Crombag (2000).

46 Dat geldt voor elke fase van de vergelijking. Dat begint ermee dat beslist moet worden welke kenmerken van een aangeleverde afdruk relevant zijn. De wijze waarop de afdruk vervolgens in de computer wordt ingevoerd is afhankelijk van dat onvermijdelijk subjectieve oordeel. En ook de beslissing of er al dan niet een match is, wordt genomen met behulp van visuele inspectie. HAVANK beperkt slechts het zoekgebied door potentiële matches aan te bieden. Wij lieten al eerder zien dat het verwachtingseffect bij dergelijke oordelen een grote rol kan spelen: Merckelbach, Crombag \& Van Koppen (2003).

47 Zeelenberg \& Simon (1993).

48. Zie Stoney (1997), p. 65. 
wordt 'verklaarbare verschillen'? Ook die keuze is onvermijdelijk subjectief: er zijn geen harde criteria voor die keuze. In de praktijk blijken de experts het over die keuze nogal eens oneens. ${ }^{49} \mathrm{Het}$ is gebruikelijk om dit probleem te beslissen door het werk van de dactyloscopist te laten controleren door één of meer anderen. Dat is een verstandige werkwijze, maar neemt niet weg dat ook dan de vergelijking intersubjectief is en blijft, zeker als de tweede deskundige niet geheel onafhankelijk van de eerste werkt, maar zij de gezamenlijke conclusie in onderling overleg trekken.

De zwakte van vingerafdrukkenvergelijking werd recentelijk ongewild gedemonstreerd door de $\mathrm{FBI}$ in een poging om juist van vingerafdrukken de "scientific basis and its universal acceptance" aan te tonen. In de strafzaak tegen Byron Mitchell ${ }^{50}$ stuurde de FBI de vingerafdrukken naar 53 verschillende vingerafdrukkenafdelingen in de Verenigde Staten met een dringend verzoek om hulp. ${ }^{51}$ Dat viel tegen: voor éen van de twee afdrukken van de plaats van het misdrijf vond men bij $23 \%$ van de politiekorpsen geen match met de verdachte, voor de tweede afdruk was dat bij $17 \%$ het geval. De bedroevende score lag niet aan de kwaliteit van de politiemensen, want zij hadden gemiddeld 20 jaar ervaring met vingerafdrukken. Vervolgens verzocht de FBI de afwijkende korpsen om nog eens goed naar de zaak te kijken

49. Zle daarover Evett \& Williams (1996).

50 U.S. v. Byron Mitchell, U.S. District Court Eastern District Pennsylvania (No. Crim. \#96407-1, E.D. Pa. 2000).

51 De FBI had geschreven: "The FBI needs your immediate help! The FBI laboratory is preparing for a Daubert hearing on the scientinc basis for fingerprints as a means of identification. The Laboratory's Forensic Analysis Section Latent Print Unit, is coordinating this matter and supporting the Assistant United States Attorney in collecting data needed to establish this scientific basis and its universal acceptance. $[\ldots]$ The time sensitive nature of these requests cannot be expressed strongly enough. nor can the importance of your cooperation. The potential impact of the Federal court not being convinced of the scientific basis for fingerprints providing individuality has far-reaching and potentially negative ramifications to everyone in law enforcement. The FBI wishes to present the strongest data available in an effort to insure success in this legal mater and your cooperation is a key component in achieving this result." 
en toen bleken alle korpsen behalve één (in Missouri) bereid om hun mening aan te passen aan het gewenste resultaat. Hoezo absolute oordelen?52

\section{Ontoerekeningsuatbaarheid}

Een soortgelijk probleem doet zich voor bij rapportages over de toerekeningsvatbaarheid van de verdachte. ${ }^{53}$ Sinds jaar en dag worden die geleverd door de Forensisch Psychiatrische Diensten (vroeger de districtpsychiaters) en het Pieter Baancentrum. De rechter ervaart dat kennelijk als een techniek, want een paar jaar geleden kon de minister van Justitie aan de Tweede Kamer melden dat in $95 \%$ van de gevallen een rapport van het Pieter Baancentrum over de toerekeningsvatbaarheid van de verdachte gevolgd wordt door de rechter. ${ }^{54}$ De rechter heeft dus veel vertrouwen in die rapportages, maar de vraag is of dat vertrouwen terecht is. In haar oratie bespreekt de Amsterdamse hoogleraar forensische psychologie Corine de Ruiter onder andere die vraag. ${ }^{55}$ Uit haar verhaal komt een geheel ander beeld van de psychologische pro justitia rapportages naar voren: van standaardisatie is geen sprake, van een deugdelijke risicotaxatie over toekomstig gedrag van de verdachte kan eigenlijk weinig zinvols gezegd worden en of een TBS-behandeling enig effect heeft weten we helemaal niet. Kortom: men doet maar wat. Het grote vertrouwen in dit soort rapportages door de rechter mag dan ook verbazing wekken. En ook De Ruiter pleit voor meer eisen die aan de rapportages gesteld moeten worden.

52 Er zijn ook andere beschreven gevallen waar de dactyloscopist de mist in ging. Zie bijvoorbeeld over de Schotse zaak waarin nota bene een politievrouw de verdachte was Grieve (1999). Zie over het verloop van die zaak http://www.clpex.com/McKie.htm. Zle bijvoorbeeld ook Heath \& Bernton (2004).

53 Zie Artt. 37 e.v. Sr. en de regeling voor observatieonderzoek Artt. 196 e.v. Sv.

54 Om precies te zijn: van de 202 rapportages van het Pieter Baancentrum uit 1998 en 1999 in zaken waarin de rechter voor juni 200 uitspraak heeft gedaan, werd in 83 gevallen TBS met bevel tot verpleging geadviseerd. De rechter volgde dat advies in 79 zaken. Zie Tweede Kamer [1999-2000], 26800 VI, nr. 81. Zle ook Malsch (1998).

De Ruiter (2000). 
De kritiek richt zich op de kwaliteit van de forensische rapportages. Weinigen hebben zich echter afgevraagd of het rapporteren over de toerekeningsvatbaarheid wel een zinvolle bezigheid is. ${ }^{56}$ Dat is het namelijk meestal niet. Kort gezegd, ${ }^{57}$ vergt een psychologisch of psychiatrisch oordeel over de toerekeningsvatbaarheid de twee volgende stappen. Ten eerste moet worden vastgesteld wat de psychische toestand van de verdachte was ten tijde van het delict. Welnu, wij hebben geen methoden waarmee wij de psychische toestand van iemand, pakweg, zes maanden geleden kunnen vaststellen. Daarop zijn wel uitzonderingen: als iemand nu zwakzinnig is, kan men gevoeglijk aannemen dat hij dat ook een half jaar geleden was. Bij acute psychische toestanden is dat echter in principe onmogelijk. Hoe weten wij of de huidige psychose van de verdachte al bestond ten tijde van het misdrijf en niet daarna is ontstaan, zoals door het plegen van het misdrijf, het opsporingsonderzoek of de detentie? Dat kunnen wij niet valide vaststellen.

Ten tweede moet de psychiater dan nog beslissen of er een causale relatie bestaat tussen de psychische toestand ten tijde van het delict en het gepleegde misdrijf. De psychiater heeft daarvoor slechts één informatiebron: het verhaal van de verdachte zelf. De verdachte heeft belangen bij het verhaal dat hij de psychiater voorspiegelt. Maar zelfs als de verdachte zijn best doet eerlijk te zijn tegen de psychiater en hem niet probeert het schip in te laten gaan, veronderstelt dit dat de verdachte in staat is tot zinvolle introspectie. Quod non: wij weten zelden wat de beweegredenen van ons eigen gedrag zijn. ${ }^{58}$ Een derde onoverkomelijke barrière voor het causale oordeel is dat het geheel van de toerekeningsvatbaarheid veronderstelt dat er een vrije wil is die bij de ontoerekeningsvatbare verdachte afwezig is. Dat wordt helemaal een rommeltje, want de vrije wil is een niet onderzoekbaar begrip. 59

56 Daarop zijn uitzonderingen. Zie bijvoorbeeld De Ruiter (2000), Derks (2001) en Brand (2001).

57 Ik bespreek dit uitgebreider in Van Koppen (2004).

58 Zie hierover recent Wilson (2002).

59 Zie hieronder bijvoorbeeld Crombag et al. (1994), hoofdstuk 13. Zle ook Bargh \& Ferguson (2000) en Sappington (1990). 
Ik stelde daarom recentelijk voor het begrip toerekeningsvatbaarheid uit de wet te schrappen.60 Het is daarop doodstil gebleven. Hoe komt dat nu? Nader beschouwd lijken het veld van de dactyloscopie en dat van het vaststellen van de toerekeningsvatbaarheid wel wat op elkaar: er wordt nauwelijks discussie gevoerd over de fundamenten van het vak. Het ontbreken van een wetenschappelijke discussie wordt vermoedelijk veroorzaakt door het feit dat beide gebieden bevolkt worden door een kaste van deskundigen die met vinger- en toerekeningsvatbaarheidsoordelen hun brood verdienen en voor hun werk geen emplooi kunnen vinden buiten het forensische veld. ${ }^{61}$ $Z_{i j}$ hebben helemaal geen belang bij een discussie over fundamentele vragen in hun vak.

Voor de rechter mogen deze gebieden er uit zien als een techniek, in feite zijn het onderontwikkelde wetenschapsgebieden. Maar hoe zou de rechter dat moeten weten? De deskundige vertelt het hem niet.

DNA

In het begin van het DNA-tijdperk leek het ook met DNA die kant op te gaan. DNA-experts begonnen ermee hun match voor te stellen als een absolute, onwrikbare uitkomst van hun onderzoek. ${ }^{62}$ Dat heeft geleid tot een soort DNA-zeeslag die, als ik de berichten mag geloven, in de Verenigde Staten op een nogal onsmakelijke manier is gevoerd. ${ }^{63}$ Inmiddels is ook het DNA-profiel in rustiger vaarwater terecht gekomen. Absolute oordelen worden niet meer gegeven en terecht. Het gebied is nog volop in ontwikkeling, maar met standaardmethoden zijn de DNA-deskundigen de rechter regelmatig behulpzaam.

Het is niet ongebruikelijk dat DNA-experts de rechtbank mededelen dat de kans dat een specimen van de plaats delict niet afkomstig is van de ver-

60 In Van Koppen (2004).

61 In die zin bijvoorbeeld Saks (1998).

62 Zie hierover Thompson (1997b) en Koehler (1993).

63 Pearsall (1989), Hoeffel (1990) en Roberts (1991) en over het einde van die oorlog Lander \& Budowle (1994). 
dachte, zeg eens, 1 op een miljard is. Dat is de zogenaamde random match probability. Dat is een getal dat zij niet zomaar uit de lucht plukken, maar dat getal is gestoeld op een nogal uitbundige hoeveelheid onderzoek die inmiddels over DNA-profielen is gedaan. ${ }^{64}$ Het vaststellen van een DNA-profiel is inmiddels danig gestandaardiseerd en geautomatiseerd. Het is ook wettelijk geregeld, waarbij zelfs bij wet een contra-expertise laboratorium is aangewezen. ${ }^{65} \mathrm{Er}$ doen zich zo weinig problemen voor dat dit contralaboratorium niet vaak wordt ingeschakeld en als dat toch gebeurt altijd tot dezelfde conclusie komt, zo meldde het hoofd van dat laboratorium, Peter de Knijff mij.

Wilde wetenschap is ook hier schijnbaar techniek geworden. Ik zeg "schijnbaar" omdat ook over DNA nog heel wat te zeggen valt en dat deden onlangs Thompson en zijn collega's in het Joumal of Forensic Sciences. ${ }^{66} \mathrm{Zij}$ wijzen erop dat fouten gemaakt worden. Zo zijn er laboratoriumfouten, die niet zozeer in het laboratorium hoeven te hebben plaatsgevonden, maar ook gemaakt kunnen worden op de plaats delict. Er bestaan inmiddels ook beschrijvingen van zaken waarin dergelijke fouten aan het licht zijn gekomen, zoals het omwisselen van het sample van het slachtoffer en van de verdachte. 67

De mate waarin dergelijke fouten voorkomen, kan moeilijk worden onderzocht, want dat lijkt in zekere zin op het zoeken naar een zeilschip op de Stille Oceaan. Stel dat enige relevante fout in 1 op de 1000 zaken wordt gemaakt. Thompson en collega's geven een instructieve tabel waarin zij demonstreren dat een random match probability van 1 of een miljard al bij een kans op een laboratoriumfout van 1 op de 1000 aanzienlijk minder zekerheid biedt. Een simpele vraag aan de DNA-deskundige zou dus kunnen zijn of hij met droge ogen kan beweren dat de kans op een fout ergens in de keten tussen plaats delict en deskundigenrapport fors kleiner is dan 1 op de 1000 .

64 Zle Kloosterman (2002).

65 Het human geneticaloboratorium van de Universiteit Leiden.

66 Thompson, Taroni \& Aitken (2003).

67 Zie bijvoorbeeld Thompson (1997a). 
De redenering van Thompson en collega's vergt enige uitleg. En die is gebaseerd op Bayesiaanse statistiek. Deze is vernoemd naar dominee Bayes die een model ontwierp waarmee men in staat is een subjectief oordeel over de waarschijnlijkheid van een gebeurtenis - bijvoorbeeld de kans dat een verdachte schuldig is - aan te passen op grond van de diagnostische waarde van een bewijsmiddel. Ik zal $u$ niet vermoeien met alle ins en outs van het Bayesiaanse model, want dat is al op vele plaatsen uitgelegd. ${ }^{68}$ De relevante elementen zijn hierbij de volgende: de a priori waarschijnlijkheid dat de verdachte schuldig is - dat wil zeggen de kans op schuld voordat men van het bewijsmiddel kennis nam -, de kans dat men dit bewijsmiddel zou aantreffen als de verdachte schuldig is en de kans dat men dit bewijsmiddel zo zou aantreffen als hij onschuldig is en als vierde element de a posteriori kans van schuld - dat wil zeggen het oordeel over de schuld van de verdachte na kennisname van dit bewijsmiddel. Die a posteriori kans is dan weer de a priori kans voor kennisname van het volgende bewijsmiddel.

In Dubieuze Zaken hebben Hans Crombag, Willem Albert Wagenaar en ik al laten zien dat Bayesiaanse statistiek niet bruikbaar is als model voor de rechterlijke beslissing. ${ }^{69}$ Dat is niet alleen zo omdat rechters helemaal niet op die manier redeneren, maar ook omdat bewijsmiddelen zelden netjes in een getal kunnen worden uitgedrukt. Bovendien, en dat is misschien het belangrijkste argument tegen Bayes in het strafrecht, veronderstelt het model dat bewijsmiddelen onafhankelijk van elkaar zijn en niet, zoals in de werkelijkheid van het strafrecht het geval is, juist een samenhangend netwerk van argumenten vormen. Maar daarop kom ik weldra terug.

Niettemin kan Bayes aan de bespreking van sommige problemen bij goed kwantificeerbare bewijsmiddelen een bijdrage leveren. En dat deden Thompson en collega's op fraaie wijze voor DNA. Zij lieten met Bayes de betrekkelijkheid zien van de random match probability als rekening gehouden wordt met mogelijke fouten in de keten van het onderzoek van de technische recherche op de plaats delict tot en met interpretaties van de laborato- 
riumuitkomsten door het NFI. De tot nu toe verzwegen kans op laboratoriumfouten mag niet verwaarloosd worden en kan de ferme conclusies van DNA-deskundigen schipbreuk laten lijden.

\section{DNA- en vingerafdrukbestanden}

Die kans is het meest desastreus als sprake is van wat zij noemen een DNAdragnet, of zoals wij dat eerder een noemden: trawlermethode. ${ }^{70} \mathrm{De}$ essentie van een dergelijke methode is dat men een groot net door zee haalt in de hoop dat daarin een visje blijft hangen. Normalitair heeft men te maken met een verdachte die op andere gronden dan DNA-onderzoek verdacht is geworden, bijvoorbeeld omdat hij op de plaats delict is gezien ten tijde van het misdrijf. Tegenwoordig is het echter bon ton om DNA-databestanden op te bouwen van zo veel mogelijk verschillende individuen. Voor elk van de personen in zo'n gegevensbestand is de kans bij voorbaat bijzonder gering dat hij de dader is. De a priori waarschijnlijkheid is dus klein. Als dan iemand verdacht wordt doordat met een zoektocht in zo'n bestand zijn DNA-profiel matcht, leiden mogelijke laboratoriumfouten ertoe dat de a posteriori waarschijnlijkheid van diens schuld niet noemenswaardig groter is. Een voorbeeld: stel de a priori kans is 1 op 1000. De random match probability is bijvoorbeeld 1 op een miljard en de kans op een laboratoriumfout is 1 op 1000. Dan is de kans dat de verdachte de dader is bij een match in het DNAbestand nog slechts $50 \% .{ }^{71}$ Dat lijkt mij volstrekt onvoldoende om iemand zonder aanvullend bewijs te veroordelen.

i lk keer terug naar vingerafdrukken. De vingerafdrukkendatabase is vele malen groter dan de DNA-database. En vingerafdrukkenonderzoek is aanzienlijk subjectiever dan DNA-onderzoek ${ }^{72}$ en daarmee is de kans op laboratoriumfouten ook aanzienlijk groter. Rechters zouden dus vingerafdrukken-

70 Crombag et al. (1994), pp. 148-149.

71 Voorbeeld ontleend aan Thompson et al. (2003). Tabel 1, waar ook de berekening kan worden gevonden.

72 Saks (1998) en Stoney (1997). 
bewijs na een match in een databestand niet zonder meer voor het bewijs moeten accepteren.

Aan uw gezichten zie ik dat $\mathrm{u}$ mij nog niet gelooft. Laat ik dan een wat alledaagser voorbeeld geven van precies hetzelfde probleem. Stel een moord is gepleegd en er is een getuige die direct na het misdrijf een zwarte Volvo V70 heeft zien wegrijden. $U$ wordt verdacht van de moord omdat $u$ eerder met het slachtoffer hevige ruzie heeft gemaakt in het cafê en voor het overige behoorlijk belang heeft bij diens dood. En u heeft een zwarte Volvo V70. Die zaak ziet er redelijk stevig uit.

Maar stel nu dat $u$ het slachtoffer niet kent en voor het overige geen relatie tussen $\mathrm{u}$ en het slachtoffer gelegd kan worden. Uit de gegevens in Veendam blijkt dat u de enige bent met een zwarte Volvo V70 die in de woonplaats van het slachtoffer woont. Zou de rechter dat als doorslaggevend bewijsmiddel moeten accepteren? Nee toch? Maar dat is precies wat wel van de rechter wordt gevraagd na een zoektocht in DNA- of vingerafdrukbestanden.

En dit is de tweede paradox die ik aan $u$ wil voorleggen. In deskundigengebieden die aan de rechter gepresenteerd worden als technieken laten deskundigen ongenoemd welke kritische vragen gesteld zouden kunnen worden bij hun rapportages. De rechter kent die vragen niet en zou daarvoor alleen bij de deskundige zelf te rade kunnen gaan. Maar die zegt het niet.

\section{Dienstroosters}

En nu houd ik weer gauw op met Bayes, want als men dergelijke statistiek gaat toepassen in het recht, loopt het snel mis. Dat mocht Lucy de B. onlangs ervaren. Lucy de $B$. is de Haagse verpleegster die vervolgd werd voor elf moorden op patiënten. De deskundige, Henk Elffers, had op grond van een analyse van dienstroosters berekend dat de kans uiterst klein is dat uitsluitend Lucy de B. bij toeval in haar diensten alle elf doden zou treffen terwijl tijdens de diensten van haar collega's geen doden vielen. ${ }^{73} \mathrm{Zijn}$ klas-

73 Omdat Elffers het niet over Lucy de B. wilde hebben, beschreef hij zijn methode aan de 
sieke, niet Bayesiaans, statistische aanpak leidde tot de conclusie dat de kans dat Lucy niets met de doden te maken zou hebben uiterst gering is. Hij berekende die kans op 1 op de 342 miljoen. Wat Lucy ermee te maken heeft. laat hij uiteraard over aan het oordeel van de rechter. Daarbij doen zich verschillende mogelijkheden voor, zoals: Lucy heeft de patiënten om het leven gebracht. Maar ook: Lucy is een uiterst slechte verpleegster die patiënten onder haar handen laat sterven of Lucy draait het type diensten waarin patiënten plegen te sterven of Lucy is juist een uiterst goede verpleegster, zodat haar collega's de moeilijke en riskante gevallen aan haar overlaten. Welke van deze conclusies, en nog andere mogelijke conclusies, de juiste is, moet de rechter beoordelen. De conclusies van Elffers vormen op die manier slechts een bouwsteen waarvan de rechter gebruik kan maken. De rechter zal daarnaast over ander bewijs moeten beschikken, wil hij tot het oordeel kunnen komen dat Lucy de patiënten om het leven heeft gebracht.

Men zou het statistische materiaal dat in de dienstroosters verscholen zit nog op een andere manier kunnen waarderen. En dat deden twee deskundigen van de verdediging in het proces tegen Lucy de B. en ook De Vos, die daarover een artikel in het Nederlands Juristenblad schreef. ${ }^{74}$ Dat artikel blinkt niet uit door helderheid, maar ik heb mij erdoorheen geworsteld. De Vos staat een Bayesiaans statistisch model voor.

Ik zei al dat het Bayesiaanse model onder meer niet bruikbaar is omdat de meeste bewijsmiddelen niet gekwantificeerd kunnen worden. Het door Elffers geleverde bewijsmiddel is daarop een uitzondering. Maar als je dat Bayesiaans wil aanpakken, moet je beginnen met een a priori waarschijnlijkheid. En daar zit nu net het probleem. Het vaststellen van die subjectieve a priori waarschijnlijkheid is iets waarover de deskundige zijn mond moet houden en als hij dat toch niet doet, wordt de redenering al snel onzinnig.

De Vos stoort zich niet daaraan en schat die a priori waarschijnlijkheid op I op de 400.000 , want er zijn 40.000 verpleegsters in Nederland en zo eens

hand van een fictief geval in het Nederlands Juristenblad: Elffers (2003). Zle voor een reactie De Vos (2004). Zie ook Elffers (2004).

De Vos (2004). 
in de tien jaar, denkt hij, komt een verpleegstersmoord voor. Dan komt hij met enige berekeningen uit de losse pols tot een kans dat Lucy schuldig is van 8 promille. Maar deugt zijn uitgangspunt? Nee dus. Er deugt zoveel niet aan zijn a priori waarschijnlijkheid dat ik nauwelijks weet waar ik moet beginnen. Laat ik er allereerst een ander voorbeeld tegenover stellen. In $\mathrm{Ne}$ derland wordt nog wel eens een moord gepleegd. ${ }^{75} \mathrm{Er}$ zijn 16.000.000 Nederlanders. De a priori kans dat ik een bepaalde moord heb gepleegd is derhalve 1 op 16.000.000. En dus kan ik in termen van De Vos zelden daarvoor worden veroordeeld, want je moet wel met erg sterk bewijs komen om een kansverhouding van 1 op 16 miljoen ten gunste van de verdachte te veranderen in een a posteriori kansverhouding die voldoende is voor een veroordeling. Maar eigenlijk is 1 op 16.000 .000 nog te ongunstig voor de verdachte. Want hoe weten wij dat een Nederlander de moord pleegde? Dat weten wij niet bij voorbaat en dus zou de kansverhouding op de omvang van de wereldbevolking gebaseerd moeten zijn: 1 op 3,5 miljard dus.

Met de a priori kans speelt De Vos vals, want hij heeft stiekem al naar het bewijs gekeken. Hij neemt bij voorbaat aan dat de moorden door een verpleegster zijn gepleegd. Hij neemt bovendien aan dat er sprake is van moord en niet van natuurlijke dood. En met zijn verhouding van 1 op 400.000 neemt hij zelfs aan dat verpleegsters nooit langer dan een jaar hun beroep uitoefenen, want hoe kun je anders het aantal in Nederland werkzame verpleegsters met 10 vermenigvuldigen? En zouden al die 400.000 verpleegsters evenveel toegang hebben gehad tot de slachtoffers? De Vos demonstreert op deze manier fraai dat het model van Bayes niet bruikbaar is in het strafrecht.

Broeders en Sjerps pakten dat onlangs in een ingezonden brief aan het Handelsblad wat slimmer aan, maar laten in hun brief ook het grootste probleem met a priori kansen in de Bayesiaanse statistiek zien. ${ }^{76}$ Ook zij vinden dat voor het gebruik van Elffers' berekening eerst een subjectieve a priori waarschijnlijkheid moet worden vaststellen van de kans dat Lucy de hand 
had in de sterfgevallen. Zij schrijven dan: "Deze subjectieve kans kunnen wij bijvoorbeeld bepalen aan de hand van het overige bewijs in de zaak." Let wel: Broeders en Sjerps zijn van het NFI. Zij stellen in feite voor om als NFIdeskundige eerst het gehele dossier - zoals alle getuigenverklaringen - te wegen en vervolgens aan de hand daarvan een waardering te geven van hun laboratoriumresultaten. Daarbij passen twee opmerkingen. Ten eerste: de essentie van een a priori kans is nu net dat die subjectief wordt vastgesteld voordat van het bewijs kennis is genomen. Ten tweede is dit een drastische verandering ten opzichte van de manier waarop het NFI op dit moment werkt. Maar daarop kom ik zo terug.

Met een Bayesiaanse benadering wordt de rol van de getuigendeskundige in extremo uitgebreid. ${ }^{77}$ Redmayne schrijft daarover: de Bayesiaanse expert "betrekt idealiter alle beschikbare informatie in zijn overwegingen, waaronder verklaringen van getuigen die bijvoorbeeld zeggen 'de inbreker stond slechts op een meter afstand toen hij met een baksteen het raam ingooide.' Het zal duidelijk zijn dat dergelijke verklaringen niet zonder meer juist hoeven te zijn: de getuige kan zich vergissen of liegen en de verdediging kan met een alternatieve hypothese komen of zelfs met verschillende alternatieve hypotheses. De expert dient de informatie te specificeren waarop hij zijn rapportage baseert, maar ook dan kunnen er problemen resteren. De informatie kan gedurende het strafproces veranderen of worden bestreden door de partijen." 78 Redmayne past op deze manier weliswaar consequent Bayes toe, maar geeft daarmee de deskundige een centrale plaats in het strafproces. Als een alwetende Pascha plaatst hij zich in het centrum van de discussie ter terechtzitting. Dat lijkt mij geen juiste rol voor een deskundige die er slechts is om de rechter te helpen.

Als deskundigen gaan rekenen, maken zij het wel vaker bont. Voor het bontste voorbeeld gaan wij naar Engeland. Sally Clark had twee kinderen verloren aan wiegendood. ${ }^{79} \mathrm{Na}$ de dood van het tweede kind werd zij ver-

77 Redmayne (2001), p. 41.

78 Redmayne (2001), p. 41, mijn vertaling.

79 R. v. Clark (Sally) EWCA Crim 1020. Zie hierover Dwyer (2003), Derbyshire (2003), Wat- 
volgd voor moord of doodslag. Zowel zij, als haar man waren sollicitor, hetgeen ongetwijfeld aan de commotie rond hun zaak heeft bijgedragen. Sir Roy Meadow - een bekend hoogleraar in Engeland en de ontdekker van het Munchausen by Proxy syndroom ${ }^{80}$ - gaf een statistisch oordeel, dat hij als volgt samenvatte in Meadow's Law: "One sudden infant death is a tragedy, two is suspicious and three is murder until proven otherwise." 81 Desgevraagd zei hij ter terechtzitting dat de kans op een wiegendood in éen gezin 1 op 8543 is en dat de kans op twee van dergelijke sterfgevallen in één gezin derhalve 1 op 73 miljoen is. ${ }^{82}$ Hij maakte daarbij verschillende fouten, ${ }^{83}$ waarvan de belangrijkste is dat hij dacht dat wiegendood van verschillende kinderen in één gezin geheel onafhankelijke gebeurtenissen zijn. Dat is niet het geval, want wiegendood heeft onmiskenbaar een genetische component. ${ }^{84} \mathrm{Er}$ was zelfs een nog extremere zaak in Engeland, die van Trupti Patel. In juni 2003 werd zij eindelijk vrijgesproken, nadat $z i j$ vervolgd was voor moord op liefst drie baby's. Bij die vrijspraak speelde een rol dat haar grootmoeder vijf baby's op dezelfde manier had verloren. ${ }^{85}$

Zelfs zonder deze misvatting heeft Meadow's redenering bizarre consequenties. De kans om bijvoorbeeld de hoofdprijs in de staatsloterij te winnen is uiterst gering. Als iemand dat toch doet, is hij volgens Meadow's Law schuldig aan fraude, "until proven otherwise."

Gelukkig, dat soort wilde wetenschappers of ontspoorde technici lopen in

kins (2000) en de reactie daarop van Meadow (2002) en daar weer reacties op door Pillai (2002) en door Lowry (2002). Sally Clark vertelde ook zelf haar verhaal in Batt (2004). De problemen in die zaak betroffen overigens niet alleen het statistisch bewijs door Roy Meadow, maar ook relevante testresultaten die door de patholoog-anatoom dr. Williams waren achtergehouden.

80 Zle Meadow (1977).

81 Meadow (1997).

$828543 \times 8543=72.982 .849$.

83 Besproken door Dwyer (2003).

84 Watkins (2000).

85 Jenkins (2003). Overigens meldde Meadow (2002) zelf later dat de veroordeling van Clark in overwegende mate was gebaseerd op pathologisch bewijs. 
Nederland niet veel rond. Maar het geval van Meadow laat zien dat de rechter zelfs tegenover een deskundige van grote statuur kritisch moet blijven. Hoedt $u$ zich dus voor statistici die menen allerlei verschijnselen in getallen uit te drukken, ook als dat in principe niet mogelijk is.

\section{De kaarten tegen de borst}

Hoe belangrijk forensische deskundigen zijn voor de rechter is niet alleen een kwantitatieve vraag, maar ook een kwalitatieve. Forensisch bewijs lijkt kwantitatief namelijk niet zo belangrijk. Er is zelfs een schatting dat op $80 \%$ van de plaatsen delict in de Verenigde Staten forensische sporen aanwezig zijn, ${ }^{86}$ maar dat die slechts in $1,7 \%$ van de zaken ook daadwerkelijk worden gebruikt. ${ }^{87}$ In ons onderzoek onder de recherche in Nederland komen wij tot gunstiger percentages, namelijk dat forensische sporen in $2 \%$ van de misdrijven helpen bij het vinden van de dader en bij $5 \%$ worden gebruikt voor het bewijs tegen een reeds aangehouden verdachte. ${ }^{88}$

Maar het zal duidelijk zijn dat forensische sporen en wat deskundigen daarover zeggen van groot belang kunnen zijn en vooral doorslaggevend in grote strafzaken. Daarbij hebben de technische recherche en het NFI een monopoliepositie, soms aangevuld met TNO. Maken zij die positie waar? ${ }^{89}$ Het antwoord daarop is volmondig ja en nee. Ja, want het zijn hardwerkende mensen die hun vak serieus nemen en het zo goed mogelijk proberen te doen. Nee, want ook zij spiegelen hun stiel als objectiever en zekerder voor aan de rechter dan de feiten rechtvaardigen. Er is wel accreditatie en dergelijke voor crime scene laboratories, maar die zijn nauwelijks toepasbaar op de meer subjectieve delen van het werk en gelden niet voor het belangrijke

86 Peterson, Mihajlovic \& Gilliand (1984).

87 Redmayne (2001), p. 17.

88 De Poot et al. (2004), p. 90 jo. p. 98.

89 Het is overigens maar wat je waarmaken noemt. "De beschermde positie van dit type instituten kan gemakkelijk leiden tot een gerichtheid op verificatie die in feite neerkomt op partijdigheid", schrijft Hildebrandt (2004), p. 191, daarover. 
voortraject: het werk van de technische recherche op de plaats delict bij het veilig stellen van sporen. 90

De mensen van het NFI stellen de resultaten van hun onderzoek zekerder voor, althans als zijnde gebaseerd op objectievere standaarden, dan de werkelijkheid rechtvaardigt. Dat wordt zelfs onder het kleed geschoffeld in het proefschrift van Ton Broeders, die chief scientist is bij het NFI. Voor zijn proefschrift had hij overigens cum laude moeten krijgen. ${ }^{91}$ Niettemin begint ook Broeders de discussie niet over het werk van het NFI. Het NFI heeft een gouden aureool en dat is terecht als je kijkt naar de kwaliteit die men tracht te leveren, maar dat is onterecht vanuit het oogpunt van de rechter. Biedt het NFI de zekerheid die het pretendeert te geven? Nee, vaak niet en niet voor alle gebieden waarop het NFI zich begeeft. Maar mijn zorgen liggen niet direct op het punt van de kwaliteit van het NFI-werk of van andere forensische deskundigen maar op de beperkeningen die zij aanleggen in hun rapportages.

Het NFI pleegt namelijk de kaarten zeer dicht bij de borst te houden. Laat ik een eenvoudig voorbeeld geven. Op de plaats van de brand worden door de technische recherche brandversnellende stoffen aangetroffen. Die worden veilig gesteld en naar het NFI gestuurd. Er is een verdachte en diens kleding wordt eveneens ingezonden met de vraag: "Zitten op de kleding van de verdachte dezelfde brandversnellende stoffen als op de plaats delict zijn gevonden?" Het rapport is helder en op het eerste gezicht duidelijk: ja, op de kleding zitten dezelfde brandversnellende stoffen. Op zichzelf genomen betekent een dergelijk rapport echter niets. Als de brandversnellende stof benzine is en de verdachte heeft net zijn auto getankt, dan zit er op zijn kleding allicht ook benzine. Als het daarentegen om een zeldzame stof gaat, is het rapport wel een zinvol bewijsmiddel en hoe zeldzamer de stof, hoe groter de diagnostische waarde daarvan is in het nadeel van de verdachte.

Het NFI heeft sterk de neiging om de rapportages op deze manier uitsluitend te beperken tot een verslag van het uitgevoerde technische laboratori- 
umwerk. ${ }^{92}$ Dat is in het algemeen jammer, maar kan onder omstandigheden even misleidend zijn voor de rechter als mijn rapport in de petjeszaak. Waarom dat zo is, vergt een klein historisch uitstapje.

\section{Het verhaal van de deskundige}

De veronderstelling dat 'iets' aan de deskundige wordt voorgelegd, hij zijn oordeel daarover geeft en het daarmee een feit is geworden, is een naïeve veronderstelling. Feiten bestaan niet. Er zijn slechts geïnterpreteerde feiten en de context van die interpretatie wordt in alle gevallen gevormd door een verhaal. Dat is geen nieuwe propositie, want wij deden die al in 1992 in $\mathrm{Du}^{-}$ bieuze Zaken $^{93}$ en anderen stelden dat al eerder voor. ${ }^{94}$ En zij kunnen het ook nog fraaier uitdrukken dan wij:

"Narratives are the only conceivable means for ordinary people to use in organizing, recalling, comparing, and testing the vast amounts of information that go into American-style legal judgments." 95

In de Theorie van Verhaal en Verankering legden wij uit dat het verhaal van de tenlastelegging noodzakelijkerwijs de vorm heeft van een verhaal. Dat verhaal van het openbaar ministerie wordt ondersteund door bewijsmiddelen maar die hebben eveneens noodzakelijkerwijs steeds de vorm van een verhaal. Die verhalen - of scenario's - zijn ook essentieel om feiten te interpreteren. Dat geldt niet alleen voor de rechter ter terechtzitting, maar misschien in nog sterkere mate voor het rechercheonderzoek. De politie heeft een scenario of, nog vaker, concurrerende scenario's nodig om de 'feiten' die

92 Nijboer (2004b) en Nijboer (2004a).

93 Crombag, Van Koppen \& Wagenaar (1992).

94 Zoals Bennett \& Feldman (1981). Bennett (1992). Pennington \& Hastie (1986) en Pennington \& Hastie (1993).

95 Bennett (1992), p. 153. 
men tegenkomt te interpreteren. ${ }^{96}$ Op basis van scenario's over hetgeen gebeurd kan zijn, structureert men de zoektocht op de plaats delict, in de wereld van het slachtoffer, maar ook in het laboratorium. En zelfs als men resultaten heeft, moeten die geïnterpreteerd worden en ook dat kan slechts met een scenario in het voor- of achterhoofd. "Science without context [...] is meaningless at best and dangerous at worst", schreven Gallop en Stockdale daarover. 97

Een eenvoudig voorbeeld kan dat duidelijk maken. Stel de inbraak is gepleegd doordat de dader een steen door de ruit heeft gegooid. Bij onderzoek blijkt op de kleding van de verdachte glas aanwezig te zijn met dezelfde brekingsindex als het glas van de ingeslagen ruit. Wat dat betekent, hangt van vele factoren af. Ten eerste natuurlijk hoe indicatief dezelfde brekingsindex is voor de vraag of de splinters van de litigieuze ruit afkomstig zijn. Daarnaast is van even groot belang hoe ver de dader van de ruit stond en van het verhaal dat de verdachte vertelt. Als hij zegt niet ter plaatse te zijn geweest, heeft het forensische onderzoek geheel andere betekenis dan als hij zegt dat hij vlak naast de ruit stond, maar iemand anders de ruit heeft ingegooid. 98 Voor de waardering van dit forensische onderzoek zijn dus ten minste twee verhalen belangrijk: het verhaal van het hoe en de merites van glasonderzoek en het verhaal dat de verdachte en getuigen vertellen over het misdrijf.

Bewijs en dus ook het deskundigenbewijs staat niet los van het overige bewijs in een zaak. ${ }^{99}$ Het krijgt slechts betekenis binnen een verhaal of scenario of zelfs binnen verschillende scenario's. Hoe belangrijk een scenario is om bewijs te begrijpen, laat de balpenzaak zien, een zaak die ook al werd

98 Ik gebruik dit verhaal niet bij toeval. Het werd namelijk ingezet ter introductie van Bayesiaanse statistiek in het forensisch veld door Evett \& Buckleton (1990) en Evett, Lambert \& Buckleton (1995). Zie voor een overzicht Evett (1991). Aitken (1995) en Redmayne (2001). De geschiedenis van deze casus in de literatuur laat zien tot welke gekunstelde constructies men moet komen om een verhaal om te zetten in lets dat Bayesiaans te behappen is. 
besproken door Hans Crombag bij zijn Maastrichtse afscheidsrede. ${ }^{100}$ De verdachte zou op 26 mei 1991 zijn moeder om het leven gebracht hebben met een Bic balpen. Zijn moeder was aangetroffen met een balpen die door haar rechteroog naar binnen was gedrongen in de linker hersenhelft. De balpen had haar dood veroorzaakt. De zoon zou de balpen in haar oog hebben gebracht op een bijzondere manier. Volgens het openbaar ministerie zou hij met een kruisboog de pen hebben afgeschoten in de richting van zijn moeder.

Het alternatieve, en onschuldige, scenario was dat de moeder met de balpen in de hand was gevallen en bijzonder ongelukkig terecht was gekomen. In deze zaak kon de rechter beschikken over het oordeel van vele deskundigen, die zich deels op eigen initiatief hadden gemeld. Een hoogleraar oogheelkunde uit Groningen meende bijvoorbeeld dat het letsel alleen door een val in de balpen veroorzaakt zou kunnen zijn. ${ }^{101}$ Weer anderen probeerden het schieten uit op "preparaten van mensen die zich ter beschikking van de wetenschap hebben gesteld". ${ }^{102} \mathrm{Zij}$ kwamen tot het oordeel dat de door het openbaar ministerie beschreven gang van zaken onmogelijk was. Niettemin veroordeelde de rechtbank de verdachte op 13 oktober 1995.

In hoger beroep kon het Hof beschikken over rapporten van nog meer deskundigen, waaronder het Gerechtelijke Laboratorium (nu NFI) in Rijswijk dat ook proeven uitvoerde. Het Hof sprak de verdachte vrij, maar niet omdat het zich door al die deskundigen had laten overtuigen. Daarover zegt het Hof in het arrest: "De proeven door deskundigen in deze zaak uitgevoerd [...] zijn qua aard, aantal en reikwijdte te beperkt geweest om op grond van de resultaten daarvan reeds onomstotelijk te kunnen vaststellen, zoals de verdediging beoogde, dat mevrouw De $\mathrm{M}$. niet door misdrijf om het leven is gekomen." "Een vreemde wending", noemde Hans Crombag dat in zijn afscheidsrede. Maar sloeg het Hof niet, onbedoeld, de spijker op de kop?

100 Crombag (2000). Zie voor een uitvoeriger bespreking van die zaak Van der Veer \& Sennef (1999), Feteris (1999) en Dingley (1999).

101 Zie hierover Rompen, Meek \& Van Andel (2000).

102 Zie Van Andel (1996). 
De discussie in de balpenzaak draaide steeds om de strijd tussen twee scenario's. Aan de ene kant het onschuldige scenario van een ongelukkige val. Aan de andere kant het kruisboogscenario van het openbaar ministerie. Dat laatste scenario was ingegeven door de therapeute van verdachte Jim. $Z i j$ was naar de politie gestapt met een verhaal dat Jim haar in therapie zou hebben verteld, namelijk dat hij zo'n bekende zeskantige Bic balpen met een kruisboog had afgeschoten op zijn moeder en zodoende zijn moeder om het leven had gebracht. Aan dat scenario zat het openbaar ministerie vast, maar dat scenario was, ook zonder de bijdrage van deskundigen, behoorlijk onwaarschijnlijk. Ten eerste zou het openbaar ministerie een verklaring moeten leveren waarom de verdachte niet een pijl, maar nota bene een balpen zou afschieten. Ten tweede eist het scenario van het openbaar ministerie een verklaring dat moeder tijdens het richten en schieten recht de schutter is blijven aankijken en zich niet afgewend heeft of is weggedoken.

$\mathrm{Er}$ is wel een schuldig scenario dat, althans op het eerste gezicht, op een grotere validiteit kan bogen. Dat is ook het scenario dat, naar verluid, het rechercheteam dat op die zaak zat, aanhing. Namelijk dat de verdachte, staande achter zijn moeder, met de hand de pen in haar oog heeft gedreven. Als het openbaar ministerie dit scenario had gepresenteerd, bijvoorbeeld in hoger beroep, was in één klap al het geëxperimenteer met varkens en mensenhoofden vrijwel zinledig geworden. ${ }^{103}$

103 Dit laat onverlet dat over het oordeel voor het kruisboogscenario door Rompen et al. (2000) ook gesteggeld wordt en wel door van Duijnen (2001) en Van Leuven, Visser \& Geradts (2002). 


\section{Technische en scenariorapportages}

Zonder scenario geen zinvol deskundigenrapport, zou je zo zeggen. Als je rapporten van het NFI overziet, lijkt dat idee daar nog niet doorgedrongen. $\mathrm{Nu}$ heeft het NFI het ook niet gemakkelijk. Overheidslaboratoria werken primair voor de politie ${ }^{104}$ en hun werk wordt gestuurd door het verhaal van de politie en door hetgeen de technische recherche op de plaats delict verzamelde. ${ }^{105}$ In eerste instantie wordt het werk van het NFI dus gestuurd door de wens een dader te vatten en bewijs tegen een aangehouden verdachte te leveren. Daar is niets mis mee. De wens om een veroordeling te bereiken, kan ervoor zorgen dat bewijs wordt gevonden dat zonder die wens gemist zou zijn. ${ }^{106}$ Maar de rapporten van het NFI blinken uit doordat zij zich uitsluitend bepalen tot een verslag van het technische onderzoek dat is verricht. Dat kan tot merkwaardige situaties leiden. Ik geef een voorbeeld.

In de Schiedammer Parkmoord is naar verluid het meest uitgebreide technische onderzoek in Nederland ooit uitgevoerd. ${ }^{107}$ In die zaak werd een 10-jarig meisje in het Beatrixpark in Schiedam gewurgd en wel op klaarlichte dag aan het einde van de middag in een druk park. Haar 11 -jarige vriendje was daarbij. De dader heeft ook geprobeerd hém te wurgen, maar het jongetje heeft het er levend vanaf gebracht. In de bosjes waar de moord is gepleegd, zijn veel sporen veilig gesteld, evenals op een aantal andere relevante plaatsen in het park. Dat levert lange lijsten met onderzochte sporen op in het dossier. Een deel is op DNA onderzocht, een deel kennelijk niet, althans daarover geeft het dossier geen uitsluitsel. Bij de vastgestelde DNAprofielen zitten er natuurlijk veel van het meisje en van het jongetje, met twee uitzonderingen. Onder de nagels van het meisje en op haar laars wordt DNA gevonden met het profiel van een en dezelfde onbekende man. Dat was

104 In Nederland wordt het NFI vrijwel altijd door politie of officier van Justitie Ingeschakeld. Zle Van Kampen (2000).

105 Zie over de problemen die dat in de Verenigde Staten teweeg brengt Kelly \& Wearne (1998) en Office of the Inspector General (1997).

106 Posner (1999), pp. 1488-1493.

107 Zie over die zaak uitgebreider Van Koppen (2003a). 
niet het profiel van het jongetje, maar ook niet van de inmiddels veroordeelde verdachte. Van de verdachte is nergens op de plaats delict DNA-materiaal gevonden.

Wat dat allemaal zou kunnen betekenen, komen wij uit de vele rapportages van het NFI in deze zaak niet te weten. Ter terechtzitting opperde de deskundige van het NFI desgevraagd dat het DNA van de vreemde man op het meisje afkomstig zou kunnen zijn van een klasgenoot waarmee zij fysiek contact zou hebben kunnen gehad. Toen ik dit verhaal vertelde aan de jongens van de Forensic Science Service in Engeland keken zij mij glazig aan en vroegen: "En toen?" Ik zei: "Wat, en toen?" "Nou, wat leverde het DNAonderzoek op de school op?" Want in Engeland zou vervolgens bij alle jongens op de school van het meisje DNA zijn afgenomen om dit scenario op zijn merites te onderzoeken, zo vertelden zij mij.

Ik kan het niet vaak genoeg herhalen en heb dat ook al meerdere keren opgeschreven: 108 DNA-profielen bewijzen niets, althans niet meer dan dat met een zekere graad van waarschijnlijkheid het DNA-profiel van de verdachte overeen komt met dat van een spoor van de plaats delict. DNA gaat pas bijdragen aan het bewijs als duidelijk wordt welke betekenis aan het spoor in de context van het misdrijf gegeven kan worden. Een scenario is derhalve onontbeerlijk.

Nu wordt het werk van het NFI ook wel degelijk door scenario's gestuurd. De technische recherche gaat op de plaats delict niet in het wilde weg sporen verzamelen. Dat kan ook niet, want zelfs in een kleine ruimte kan niet alles worden onderzocht. Men richt zich dus op de plekken waar men op grond van ervaring of het specifiek sporenbeeld op de plaats delict het meest waarschijnlijk dadersporen denkt aan te treffen. Vooral dat laatste is scenariogestuurd: men tracht de gebeurtenissen te reconstrueren en dan te beoordelen waar de dader vermoedelijk iets heeft achtergelaten. ${ }^{109}$ Dat scena-

108 Zoals in Van Koppen \& Malsch (2001).

109 Zle over dit zoekproces De Poot et al. (2004). In toenemende mate wordt hierbij geprobeerd om reeds op de plaats delict in samenspraak tussen tactische en technische recherche het zoeken naar sporen te verbeteren door bijvoorbeeld ook rekening te houden 
rio blijft echter impliciet en zelfs vaak voor het NFI verborgen. ${ }^{110}$ Maar zodoende zijn het sporenonderzoek en het laboratoriumwerk minder behulpzaam aan de rechter dan zij zouden kunnen zijn.

Dit alles wordt ingegeven voor de heersende leer dat deskundigen zich nauwgezet niet mogen begeven op het terrein van de rechter. ${ }^{111}$ Deskundigen zouden zich vooral niet moeten uitlaten over ultimate issues, waaronder Marijke Malsch bijvoorbeeld ook rekent de toerekeningsvatbaarheid van de verdachte voor het misdrijf. De taak van de deskundige is, volgens Malsch, empirisch van aard, terwijl de taak van de rechter normatief is. ${ }^{112}$

Deskundigen moeten zich dus strikt beperken tot de feiten die aan hun oordeel zijn onderworpen. ${ }^{113}$ Dat is een wel zeer beperkte interpretatie van hetgeen in de wet staat. In art. $343 \mathrm{~Sv}$ wordt het werk van de deskundige als volgt omschreven: "Onder verklaring van een deskundige wordt verstaan zijn bij het onderzoek op de terechtzitting medegedeeld gevoelen betreffende hetgeen zijne wetenschap hem leert omtrent datgene wat aan zijn oordeel onderworpen is." Maar in art. 227, lid $1 \mathrm{~Sv}$, dat is ondergebracht in de regeling voor het gerechtelijke vooronderzoek, lijkt de wetgever uit te gaan van een veel ruimere taak van de deskundige. Hij heeft de taak de rechtercommissaris "voor te lichten of bij te staan, alsmede, zo nodig, een onderzoek in te stellen." Dat lijkt ook sterk op de Engelse regeling, waar: "An expert witness should provide independent assistance to the Court by way of objective unbiased opinion in relation to matters within his expertise [...]."114

De hulp aan de rechter kan in veel gevallen - afhankelijk van de aard van

met verhalen die directe getuigen vertellen. Zie daarover Van der Ham \& Nouwens (2002).

110 Daaraan probeert men bij het nfi overigens wel wat te doen. De zogenaamde frontdesk wordt steeds belangrijker. Daarmee probeert men in overleg met de recherche het laboratoriumwerk zo zinvol mogelijk te laten verlopen. Zie Nederlands Forensisch Instituut (2003).

111 Zie bijvoorbeeld Malsch (2001).

112 Malsch (2001), p. 189.

113 Dwyer (2003).

114. National Justice Compania v. Prudential Assurance (The Ikarian Reefer) 2 Lloyd's Rep 68. 1993. 
de zaak en het onderwerp dat aan de deskundige werd voorgelegd - slechts worden geboden als de deskundige zich verplaatst in het probleem waarvoor de rechter staat en met de rechter meedenkt. Dat kan niet anders dan door scenario's te onderzoeken en een oordeel te geven over de rol van het onderzochte in elk van de scenario's.

Hoe dat kan gebeuren, laat ook het werk van het NFI zien, nu in de Deventer Moordzaak. Hier lijkt het NFI af te stappen van de traditie om de kaarten dicht tegen de borst te houden. Ik juich dat toe.

Over de Deventer Moordzaak is al veel geschreven.115 Voor degenen die langdurig op zee verkeerden: op 23 september 1999 werd mevr. Wittenberg in haar huis in Deventer om het leven gebracht. Daarvoor is door het Hof Arnhem veroordeeld Ernest Louwes, nadat hij overigens door de rechtbank was vrifgesproken. De Hoge Raad heeft bewilligd in een herzieningsverzoek in die zaak ${ }^{116}$ en de zaak verwezen naar het Hof Den Bosch. ${ }^{117}$

Men is het er inmiddels over eens dat de bewijsvoering door het Hof Arnhem in ieder geval op één punt onjuist was. Het Arnhemse hof had aangenomen dat een mes dat elders in Deventer was gevonden het moordwapen was. De perikelen rond het mes vormden ook voor de Hoge Raad het novum op grond waarvan men herziening toestond.

Al vrij snel bij de behandeling door het Hof Den Bosch was het mes als bewijsmiddel afgevoerd, en terecht. Maar er kwam nieuw onderzoek. Op zolder bij de Deventer politie werd de blouse gevonden die mevr. Wittenberg droeg ten tijde van de móord. Over de manier waarop die al die jaren bewaard is gebleven, is een hele discussie mogelijk. Maar laten wij aannemen dat zulks keurig is gebeurd.

Het NFI heeft de blouse opnieuw onderzocht. Ik zeg "opnieuw" omdat men toentertijd slechts gekeken heeft naar de steekpatronen in de blouse. Maar nu werd de blouse op DNA onderzocht. Op de kraag vond men een klein bloedvlekje waarvan het DNA-profiel bij dat van Louwes paste. Aan de voor-

115. Daaraan is in de pers ruime aandacht gegeven. Zie ook Van Koppen (2003b).

116. HR 1 jull 2003, LNN-nummer AE8165 Zaaknr: 00095/02 H (Deventer Moordzaak).

117. Zie voor het arrest Hof 's-Hertogenbosch 9 februari 2004, LN N-nummer AO 3222. 
zijde van de blouse werd op verschillende plaatsen eveneens hetzelfde DNA gevonden.

Maakt dit Louwes nu schuldig? Niet direct. Louwes kwam met enige regelmaat bij het slachtoffer, want hij was haar fiscaal adviseur. Hij zegt ook de ochtend voorafgaand aan het vermoedelijke tijdstip van de moord bij haar geweest te zijn. Mevr. Wittenberg was nogal in de bonen door de dood van haar man en Louwes sloeg wel eens een arm om haar heen om haar te troosten, zo zegt hij. Hij bijt op zijn nagelriemen en op die manier zou allicht een bloedvlekje van hem op de kraag van haar blouse hebben kunnen komen.

Zo op het eerste gezicht past het DNA-onderzoek even goed in een onschuldig als in een schuldig scenario en lijkt het dus niet erg relevant voor de beslissing waarvoor het Hof Den Bosch stond.

Het NFI deed echter iets nieuws. Voordat ik dat vertel, moet ik eerst iets vertellen over de manier waarop mevr. Wittenberg om het leven is gebracht. Uit het sectierapport blijkt dat een poging tot wurging is ondernomen, dat $z \mathrm{ij}$ ernstig is mishandeld, zodanig dat onder andere haar ribben zijn gebroken en dat zij vijfmaal met een mes is gestoken. De dader heeft, grosso modo, dus op drie verschillende manieren getracht haar om het leven te brengen.

$\mathrm{Nu}$ het NFI-rapport, waarin voor het eerst heel precies naar het sporenpatroon is gekeken. Ten eerste is het lichaam van mevr. Wittenberg liggend op de grond aangetroffen met een bloedspoor uit haar mondhoek recht naar beneden. Daaruit leidt het NFI af dat zij is gestoken toen zij reeds op de grond lag. Voorts is op de voorzijde van de blouse een aantal vlekken aangetroffen die mogelijk make-up zijn. En precies in die vlekken is het DNA van Louwes gevonden, terwijl men dat niet heeft aangetroffen op de onderzochte plaatsen buiten de vlekken.

De implicatie van dit alles moge duidelijk zijn. De dader heeft kennelijk eerst geprobeerd mevr. Wittenberg te wurgen. Dat lukte niet direct - en dat is ook logisch want wurgen duurt heel lang en vergt meer tijd en inspanning dan televisieseries suggereren. Maar daarmee heeft de dader make-up op zijn handen gekregen die bij de daarop volgende mishandeling op de voorzijde van mevr. Wittenbergs blouse terecht is gekomen. DNA van Louwes 
wordt op die vlekken gevonden en niet daarbuiten. Ergo, Louwes heeft mevr. Wittenberg om het leven gebracht. Dat was ook de conclusie die het Hof Den Bosch trok.

Al deze implicaties vertel ik $u$ nu en die zijn ook zo gewaardeerd door het Hof dat opnieuw Louwes veroordeelde, maar staan kennelijk niet in het rapport van het NFI. Dat is jammer, want deze nieuwe ontwikkeling bij het NFI zou daarmee sterker zijn. Een rapport als dit is aanzienlijk behulpzamer aan de rechter dan de traditionele verslaglegging van uitsluitend het technische onderzoek. Het rapport had echter ook wel iets verder mogen gaan. Zo wordt steeds gesproken over vlekken die kennelijk make-up vlekken zijn. Had men niet even de blouse door de afdeling chemie kunnen laten onderzoek om vast te stellen of dat ook werkelijk make-up was?

\section{Seksueel misbruikzaken}

Ik kom in de buurt van mijn conclusies. Soms is het verstandig als de deskundige zich beperkt tot precies datgene wat aan zijn oordeel is onderworpen. Dat geldt bijvoorbeeld voor Henk Elffers die rapporteerde over de kans dat, gezien de dienstroosters in de ziekenhuizen, éen verpleegster zoveel doden tijdens haar dienst zou hebben. In veel, en ik denk in de meerderheid, van de zaken kan de deskundige er niet omheen te expliciteren in welke scenario's zijn bevindingen passen, wat die bevindingen over concurrerende scenario's zeggen. Hij mag zich dan niet beperken tot precies datgene wat aan zijn oordeel is onderworpen, tenminste als hij aan de rechter zo veel mogelijk behulpzaam wil zijn.

Ik geef nog een voorbeeld. In een zaak die zich afspeelde in Drachten verkrachtte een man een aantal vrouwen in het park. In die zaak werden met een aantal slachtoffers herkenningsprocedures ondernomen, namelijk meervoudige confrontaties met video. En dat is de beste confrontatie die ik tot nu toe in Nederland heb gezien. Toch moest ik het Hof ook erop wijzen dat zowel de verdachte als de slachtoffers in de buurt van het park woonden en dat niet bij voorbaat kon worden uitgesloten dat zij elkaar mogelijk eer- 
der waren tegengekomen.

$\mathrm{Er}$ is een type zaken waarin het welhaast onvermijdelijk is om het gehele dossier in de beschouwingen te betrekken. Dat zijn seksueel misbruikzaken. Deskundigenverklaringen in seksueel misbruikzaken zijn extra lastig. Ten eerste gaat het vaak om uiteenlopend gedrag van de dader. Seksueel misbruikzaken variëren van eenmalig masturberen in aanwezigheid van het kind tot vele malen herhaalde verkrachting. Ten tweede vindt de aangifte vrijwel altijd plaats nadat anderen invloed hebben uitgeoefend op de verklaring van het kind. Ten derde zijn de reacties van kinderen op seksueel misbruik nogal heterogeen. ${ }^{118} \mathrm{Er}$ is dus geen vast patroon van symptomen op grond waarvan beslist kan worden dat een kind seksueel is misbruikt. ${ }^{119}$ Ten vierde ontbreken in vrijwel alle gevallen fysieke sporen en andere ooggetuigen dan het vermeende slachtoffer. Bij een deskundigenbericht over een seksueel misbruikzaak moet de verklaring van het kind dus meestal het uitgangspunt vormen voor de beschouwingen. Omdat anderen een overheersende invloed kunnen hebben gehad op de verklaring van het kind, moeten de verhoren van die anderen ook in de beschouwingen worden betrokken. Maar misschien is door het kind - of in de interactie tussen kind en bijvoorbeeld moeder - onschuldig gedrag van de verdachte verkeerd geinterpreteerd. Dus moet ook gelet worden op hetgeen de verdachte verklaart. Tegen die tijd heeft de deskundige zich in de meeste gevallen over vrijwel het gehele dossier uitgelaten en kan hij een oordeel over al die onderdelen niet omzeilen. Ook al heeft de rechter het laatste woord, de deskundige zit dan inmiddels stevig op de stoel van de rechter.

En dat is de laatste paradox die ik aan $u$ wil voorstellen. In veel zaken kan de deskundige slechts een gefundeerd en aan de rechter behulpzaam rapport schrijven over hetgeen aan zijn oordeel is onderworpen als hij zodanig alle relevante scenario's in die zaak in zijn overwegingen betrekt dat de grens tussen deskundigenwerk en rechterswerk wel erg dun wordt. Waar ligt in de Deventer moordzaak de grens tussen de uitspraak "Het DNA van

118. Fisher \& Whiting (1998).

119. Sbraga \& O'Donohue (2003). 
Louwes vinden wij op alle sporen die alleen de dader kan hebben achtergelaten" en "Louwes is de dader"? Of in veel seksueel misbruikzaken tussen " $\mathrm{Er}$ is geen reden om te twijfelen aan de verklaring van het kind" en "Vader heeft haar misbruikt"? De tweede vraag moet de rechter beantwoorden, maar het verschil met beantwoording van de eerste vraag is in veel gevallen slechts een cosmetische kwestie. Het lijkt mij, uitzonderingen daargelaten, spijkers op laag water zoeken om principieel onderscheid te maken tussen de twee typen uitspraken. ${ }^{120}$

\section{Conclusie}

Deskundigen kunnen in veel zaken de rechter zinvol helpen bij zijn beslis- $A$ sing. Maar hij kan ook de rechter de boot in laten gaan. Niet voor niets is Hans Nijboer van oordeel dat deskundigen nogal eens een min of meer kwalijke rol spelen bij geruchtmakende dubieuze zaken en rechterlijke dwalingen. 121

Als de rechter deskundigen om hulp vraagt of deskundige hulp wordt opgedrongen door openbaar ministerie of verdediging, treedt hij in een verhouding die gekenmerkt wordt door paradoxen. Het zal $u$ zijn opgevallen dat ik het daarbij niet gehad heb over communicatieproblemen die kunnen ontstaan doordat de rechter praat in juridische termen en de deskundige in zijn eigen vakjargon. De communicatie kan goed mislopen, maar kan ook praktisch worden opgelost door de tijd te nemen. ${ }^{122}$ Alles in mijn vak kan aan ontwikkelde leken worden uitgelegd, hoewel sommige onderwerpen wat meer tijd vergen dan andere. Communicatieproblemen ontstaan veelal

120. Dat werd als eerste gedaan door Thompson \& Schumann (1987) en zij noemde dit de prosecutor's fallacy. Zie ook Leung (2002) en Broeders (2003).

121. Nijboer (2004b). Zoals in Nederland de Puttense Moordzaak, Van Koppen \& Schalken (2004), of de Deventer Moordzaak, Van Koppen (2003b). Maar vooral in het buitenland kunnen ze er wat van. Zle bijvoorbeeld Huber (1991), Robertson \& Vigneaux (1995) en Foster \& Huber (1997).

122. Nijboer (2002). 
doordat de rechter op hete kolen zit en tegenwoordig productie moet draaien.

Sommige paradoxen in de verhouding tussen rechter en deskundige kunnen niet opgelost worden. Wetenschappers zijn niet gericht op het soort zekerheid waar de rechter om vraagt. Vooral op wetenschapsgebieden die volop in beweging zijn, laat de deskundige de rechter met lege handen staan. Dat is jammer, maar het droeve lot van de rechter is dat hij toch een beslissing moet nemen en zijn eigen koers moet varen.

De paradoxale verhouding tussen rechter en deskundige wordt problematisch als de rechter niet door heeft, en de deskundige hem ook niet vertelt, dat aan het deskundigenbericht meer onzekerheden verbonden zitten dan daaruit blijkt. Deze en de andere paradoxen kunnen niet opgelost worden door een oordeel te vragen aan een andere deskundige. Bovendien, is mijn ervaring, levert dat alras ter terechtzitting of in geschrift een discussie op die niet meer over de concrete strafzaak gaat, maar meer thuis hoort in het wetenschappelijke domein.

De beste, maar zeker niet een complete, oplossing voor al deze paradoxen is dat de deskundige zich realiseert dat zijn verhaal vrijwel altijd onderdeel uitmaakt of relevant is voor éen of meer scenario's die in de strafzaak aan de orde zijn. Dat plaatst het oordeel van de deskundige niet alleen in het juiste perspectief, maar levert nog een aantal andere voordelen. Ten eerste wordt de deskundige dan gedwongen zich af te vragen hoe en op welke manier zijn oordeel behulpzaam kan zijn aan de rechter. Ten tweede sluit daarmee het deskundigenbericht beter aan bij de beslissingen waarvoor de rechter staat. En ten derde zal dat bijdragen aan de transparantie van de discussie tussen deskundige en rechter. Hoever de deskundige dan moet gaan. blijft echter een kwestie van schipperen. 


\section{Dankwoord}

Mijnheer de Rector Magnificus, Dames en Heren!

Tot slot wil ik mijn dank uitspreken aan het College van Bestuur van de Universiteit Maastricht en het bestuur van de Juridische Faculteit voor het in mij gestelde vertrouwen. Ik hoop dat ik in de beperkte tijd die mij aan deze universiteit gegeven is een fikse bijdrage kan leveren aan onderzoek en onderwijs.

Heren en dames studenten, ik tracht mijn kwantitatief geringe bijdrage aan het onderwijs te compenseren door nieuwe vormen van onderwijs te introduceren. Een van de vormen is het Project Gerede Twijfel, waarin met groepen studenten intensief dossiers van complexe strafzaken worden geanalyseerd. ${ }^{123}$ Dat zijn zaken waarin de veroordeelde volhoudt dat hij ten onrechte is veroordeeld. Maar binnenkort zullen wij nog met andere nieuwe vormen komen.

Leden van de Juridische Faculteit en in het bijzonder de Capaciteitsgroep Metajuridica. Ik ben bijzonder gelukkig met de manier waarop ik in uw midden ben opgenomen. Dat geldt des te meer nu de Faculteit verkeert in een fase van heftige herstructurering.

Leden van de Interfacultaire Werkgroep Rechtspsychologie. De samenwerking met jullie is essentieel om het vak Rechtspsychologie gestalte te geven. Ik hoop dat de prettige manier waarop wij samen werken een grote belofte inhoudt voor de toekomst van de Werkgroep en voor de Nederlandse rechtspsychologie.

Dat ik hier sta, heb ik aan velen te danken. In mijn oratie bij de Vrije Universiteit, nu een half jaar geleden, heb ik de belangrijksten van hen bedankt. ${ }^{124}$ Mag ik, zoals juristen dat plegen uit te drukken, die dank hier als herhaald en ingelast beschouwen?

Voor mij is het werken en verblijven in Maastricht tot nu toe een feest.

123. Zie www.geredetwijfel.nl.

124. Van Koppen (2003c). 
Dat is het minder voor mijn vrouw Josée en onze kinderen Vere, Max en Chris, want ik ben nu nog meer van huis. Aan hen draag ik daarom mijn oratie op.

Ik heb gezegd. 


\section{Literatuur}

Aitken. C.G.G. (1995). Statistics and the evaluation of evidence for forensic scientists. Chicester: Wiley.

Andel, P. van (1996). Een dodelijke pen. NRC-Handelsblad (10 februari).

Bargh, J.A. \& M.J. Ferguson. (2000). Beyond behaviorism: On the automaticity of higher mental processes. Psychological Bulletin, 126, 925-945.

Batt, J. (2004). Stolen innocence: A mother's fight for justice - the authorised story of Sally Clark. London: Ebury.

Bennett, W.L. (1992). Legal fictions: Telling stories and doing justice. In: M.L. McLaughin \& M.J. Cody \& S.J. Read (red.), Explaining one's self to others: Reason-giving in a social context (pp. 149-164). Hillsdale, NJ: Erlbaum.

Bennett, W.L. \& M.S. Feldman. (1981). Reconstructing reality in the courtroom: Justice and judgement in American culture. New Brunswick, NJ: Rutgers University Press.

Brand, E.J.P. (2001). Het persoonlijkheidsonderzoek in het strafrecht: Een aanzet tot de gedragswetenschappelijke verantwoording van de psychologische rapportage Pro Justitia, meer in het bijzonder van de toerekeningsvatbaarheidsbepaling. Deventer: Gouda Quint (diss. KU Brabant).

Broeders, A.P.A. (2000). De forensisch deskundige in Nederland. Trema, 23, 366-372.

Broeders, A.P.A. (2002). Daubert en Saks: Het einde van de klassieke identificatiecriminalistiek? Nederlands Juristenblad, 77, 1786-1798.

Broeders, A.P.A. (2003). Op zoek naar de bron: Over de grondslagen van de criminalistiek en de waardering van het forensisch bewijs. Deventer: Kluwer (diss. Leiden).

Broeders, A.P.A. \& M. Sjerps. (2004). Gratis pech. NRC-Handelsblad (21 februari).

Brooks, C.M. \& M. Milcham. (1991). Child sexual abuse allegations during custody litigation: Conflicts between mental health expert witnesses and the law. Behavioral Sciences and the Law, 9, 21-32. 
Buruma, Y. (1996). De aandacht van de strafrechter. Arnhem: Gouda Quint (oratie Nijmegen).

Champod, C. (1995). Edmond Locard: Numerical standards and 'probable' identifications. Journal of Forensic Identification, 45, 136.

Champod, C., C. Lennard \& P. Margot. (1993). Alphonse Bertillon and dactyloscopy. Joumal of Forensic Identification, 43, 604-625.

Cohn, D.S. (1991). Anatomical doll play of preschoolers referred for sexual abuse and those not referred. Child Abuse and Neglect, 15, 455-466.

Corstens, G.J.M. (2002). Het Nederlandse strafprocesrecht (4e ed.). Deventer: Kluwer.

Crombag, H.F.M. (2000). Rechters en deskundigen. Nederlands Juristenblad, 75, 1659-1665 (afscheidsrede Universiteit Maastricht).

Crombag, H.F.M., P.J. van Koppen \& W.A. Wagenaar. (1992). Dubieuze zaken: De psychologie van strafrechtelijk bewijs. Amsterdam: Contact.

Crombag, H.F.M., P.J. van Koppen \& W.A. Wagenaar. (1994). Dubieuze zaken: De psychologie van strafrechtelijk bewijs. Amsterdam: Contact $(2 \mathrm{e}$ herziene druk).

Crombag, H.F.M. \& W.A. Wagenaar. (2000). Audite et alteram partem. Trema, 23, 93-96.

Derbyshire, D. (2003). Misleading statistics were presented as facts in Sally Clark trial. Daily Telegraph (June 12), 4.

Derks, W. (2001). Het oordeel van Hippias: Over de deskundigheid van psychiaters en psychologen en hun invloed op de strafrechtspleging. Amsterdam: De Arbeiderspers.

Dingley, A.M. (1999). The Ballpoint Case: A Wigmorian analysis. In: M. Malsch \& J.F. Nijboer (red.), Complex cases: Perspectives on the Netherlands criminal justice system (pp. 179-188). Amsterdam: Thela Thesis.

Duijnen, M.T.A. van (2001). De Leidse balpenaffaire: Een ongevraagde expertise negen jaar later. Modus, 10 (2), 24-25.

Dwyer, D. (2003). The duties of expert witnesses of fact and opinion: R. v. Clark (Sally). International Journal of Evidence and Proof, 7, 264-269.

Elffers, H. (2003). Bij toeval veroordeeld? Statistische analyse van dienstroosterdata in het strafproces. Nederlands Juristenblad. 78, 1812-1814. 
Elffers, H. (2004). "Geacht hof, het was geen toeval. De rest is aan u": Over de bescheiden rol van de statisticus als deskundige in de rechtzaal, geïllustreerd aan een dienstroosterzaak. Stator, (in druk).

Epstein, R. (2002). Fingerprints meet Daubert: The myth of fingerprint 'science' is revealed. Southern California Law Review, 75, 605-657.

Evett, I.W. (1991). Interpretation: A personal odyssey. In: C.G.G. Aitken \& D.A. Stoney (red.), The use of statistics in forensic science (pp. 9-22). New York: Ellis Horwood.

Evett, I.W. \& J.S. Buckleton. (1990). The interpretation of glass evidence: A practical approach. Journal of the Forensic Science Society, 30, 215-223.

Evett, I.W., J.A. Lambert \& J.S. Buckleton. (1995). Further observations on glass evidence interpretation. Science and Justice, 35, 283-289.

Evett, I.W. \& R.L. Williams. (1996). A review of the sixteen points fingerprint standard in England and Wales. Journal of the Forensic Identification. 46, 49-73.

Faigman, D.L. (1995). The evidentiary status of social science under Daubert: Is it "scientific," "technical," or "other" knowledge? Psychology. Public Policy, and Law, 1. 960-979.

Feteris, E.T. (1999). What went wrong in the Ballpoint Case? An argumentative analysis and evaluation of the discussion in the Ballpoint Case. In: M. Malsch \& J.F. Nijboer (red.), Complex cases: Perspectives on the Netherlands criminal justice system (pp. 159-178). Amsterdam: Thela Thesis.

Fisher, C.B. \& K.A. Whiting. (1998). How valid are child sexual abuse validations? In: S.J. Ceci \& H. Hembrooke (red.), Expert witnesses in child abuse cases: What can (and should) be said in court? (pp. 159-184). Washington, DC: American Psychological Association.

Foster, K.R. \& P.W. Huber. (1997). Judging science: Scientific knowledge and the federal courts. Cambridge, MA: MIT Press.

Gallop, A. \& R. Stockdale. (1998). Trace and contact evidence. In: P. White (red.), Crime scene to court: The essentials of forensic science. Cambridge: Royal Society of Chemistry.

Galton, F. (1892). Finger prints. London: Macmillan. 
Grieve, D.L. (1999). Built by many hands. Journal of Forensic Identification, $49,565-579$.

Groot, A.D. de (1961). Methodologie: Grondslagen van onderzoek en denken in de gedragswetenschappen. 's-Gravenhage: Mouton.

Gross, S.R. \& J.L. Mnookin. (2003). Expert information and expert evidence: A preliminary taxonomy. Seton Hall Law Review, 34, 141-189.

Gudjonsson, G.H. (2003). The psychology of interrogations and confessions: A handbook. Chicester: Wiley.

Ham, P. van der \& J. Nouwens. (2002). PD-management. Amsterdam: s.n.

Heath, D. \& H. Bernton. (2004). FBI admits fingerprint error, clearing Portland attorney. The Seattle Times (May 25).

Hildebrandt, M. (2004). Wetenschap in rechte. Trema, 27, 187-195.

Hoeffel, J.C. (1990). The dark side of DNA profiling: Unreliable scientific evidence meets the criminal defendant. Stanford Law Review, 42, 465-538.

Hofstee, W.K.B. (1980). De empirische discussie: Theorie van het sociaalwetenschappelijk onderzoek. Meppel: Boom.

Horowitz, S.W., M.E. Lamb, P.W. Esplin, T.D. Boychuk, O. Krispin \& L. Reiter-Lavery. (1997). Reliability of criteria-based content analysis of child witness statements. Legal and Criminological Psychology, 2, 11-22.

Huber, P.W. (1991). Galileo's revenge: Junk science in the courtroom. New York: Basic Books.

Jeffrey, R.C. (1992). Probability and the art of judgement. Cambridge: Cambridge University Press.

Jenkins, S. (2003). Trupti Patel and the rotten courts of Salem. The Times (June 13).

Kampen, P.T.C. van (1998). Expert evidence compared: Rules and practices in the Dutch and American criminal justice system. Antwerpen: Intersentia (diss. Leiden).

Kampen, P.T.C. van (2000). De positie van het Gerechtelijk Laboratorium: onafhankelijkheid in meer perspectieven. In: K. Boonen \& A.C. 't Hart \& T.A. de Roos (red.), Criminalistiek, forensische deskundigen en strafrechtpleging (pp. 59-73). Deventer: Gouda Quint. 
Kelly, J.H. \& P.K. Wearne. (1998). Tainting evidence: Behind the scenes at the FBI Crime Lab. New York: Free Press.

Kingston, C.R. \& P.L. Kirk. (1965). Historical development and evaluation of the ' 12 point rule' in fingerprint identification. International Criminal Police Review, 186, 62.

Kloosterman, A.D. (2002). The development and implementation of forensic DNA typing technologies in the Netherlands. Ongepubliceerd proefschrift University of Santiago de Compostela.

Koehler, J.J. (1993). DNA matches and statistics: Important questions, surprising answers. Judicature, 76, 222-229.

Koppen, P.J. van (1998). Bekennen als bewijs: Bedenkingen bij het verhoor van de verdachte. Justitiële Verkenningen, 24 (4), 61-73.

Koppen, P.J. van (2000). How psychologists should help courts. In: J.F. Nijboer \& W.J.J.M. Sprangers (red.), Harmonisation in forensic expertise: An inquiry into the desirability of and opportunities for international standards (pp. 257-275). Amsterdam: Thela Thesis.

Koppen, P.J. van (2003a). De Schiedammer parkmoord: Een rechtspsychologische reconstructie. Nijmegen: Ars Aequi Libri.

Koppen, P.J. van (2003b). Het Deventer Novum: Over een mes, een geursorteerproef en een novumconstructie door de Hoge Raad. Delikt en Delinkwent, 33, 979-994.

Koppen, P.J. van (2003c). Verankering van rechtspraak: Over de wisselwerking tussen burger, politie, justitie en rechter. Deventer: Kluwer (oratie Vrije Universiteit).

Koppen, P.J. van (2004). Weg van de toerekeningsvatbaarheid: Over rapportages over de verdachte. Trema, 27, 221-228.

Koppen, P.J. van \& H.F.M. Crombag. (2000). Oren, lippen en vingers: De waarde van oud en nieuw identificatiebewijs. Nederlands Juristenblad, 75 , 6-12.

Koppen, P.J. van \& M. Malsch. (2001). De verjaringstermijn moet blijven. Nederlands Juristenblad, 76, 525.

Koppen, P.J. van \& S.D. Penrod. (2003). The John Wayne and Judge Dee versions of justice. In: P.J. van Koppen \& S.D. Penrod (red.), Adversarial 
versus inquisitorial justice: Psychological perspectives on criminal justice systems (pp. 347-368). New York: Plenum.

Koppen. P.J. van \& M.J. Saks. (2003). Preventing bad psychological scientific evidence in The Netherlands and The United States. In: P.J. van Koppen \& S.D. Penrod (red.), Adversarial versus inquisitorial justice: Psychological perspectives on criminal justice systems (pp. 283-308). New York: Plenum.

Koppen, P.J. van \& T.M. Schalken. (2004). Rechterlijke denkpatronen als valkuilen: Over zes grote zaken en derzelver bewijs. In: J.W. de Keijser \& H. Elffers (red.), Het maatschappelijke oordeel van de rechter: De wisselwerking tussen rechter en samenleving (pp. 85-131). Den Haag: Boom.

Koppen. P.J. van \& W.A. Wagenaar. (2002). Herkennen van gezichten. In: P.J. van Koppen \& D.J. Hessing \& H. Merckelbach \& H.F.M. Crombag (red.), Het recht van binnen: Psychologie van het recht (pp. 543-572). Deventer: Kluwer.

Lamb, M.E. \& K.J. Sternberg. (1998). Conducting investigative interviews of alleged sexual abuse victims. Child Abuse and Neglect, 22, 813-823.

Lander, E.S. \& B. Budowle. (1994). DNA fingerprinting dispute laid to rest. Nature, 371, 735-738.

Lee, P.M. (1997). Bayesian statistics: An introduction (2nd ed.). London: Arnold.

Leistra, G. \& P. Nieuwbeerta. (2003). Moord en doodslag in Nederland 19922001. Amsterdam: Prometheus.

Leung, W.C. (2002). The prosecutor's fallacy: A pitfall in interpreting probabilities in forensic evidence. Medicine. Science and the Law, 42, 44-50.

Leuven, B. van, R. Visser \& Z. Geradts. (2002). Commentary on: Rompen, J.C., Meek, M.F. \& Andel, M.V. (2000) 'A cause célèbre: The so-called ballpoint muder. Journal of Forensic Sciences 45 (5), $1144-1147$. Journal of Forensic Sciences, 47, 234.

Lowry, R.B. (2002). Was it truly murder or sudden infant death symdrome? British Medical Journal, 324, 1096. 
Malsch, M. (1998). De rechter en de psycholoog: De praktijk van de forensische gedragskundige rapportage in strafzaken. Delikt en Delinkwent, 28 , 644-656.

Malsch, M. (2001). De stoel van de jurist. In: P.B. Cliteur \& H.J. van den Herik \& N.J.H. Huls \& A.H.J. Schmidt (red.), It ain't necessarily so: Opstellen aangeboden aan Prof. mr. H. Franken (pp. 183-196). Deventer: Kluwer.

Malsch, M. \& J.F. Nijboer (red.). (1999). Complex cases: Perspectives on the Netherlands criminal justice system. Amsterdam: Thela Thesis.

Meadow, R. (1977). Munchausen symdrome by proxy: Hinterland of child abuse. Lancet, 2 (8033), 343-345.

Meadow, R. (2002). A case of murder and the BMJ. British Medical Joumal, $324,41-43$.

Meadow, R. (red.). (1997). The ABC of child abuse (3rd ed.). London: BMJ Publishing.

Merckelbach, H., H.F.M. Crombag \& P.J. van Koppen. (2003). Hoge verwachtingen: Over het corrumperend effect van verwachtingen op forensische expertise. Nederlands Juristenblad, 78, 710-716.

Mnookin, J.L. (2001). Fingerprint evidence in an age of DNA profiling. Brooklyn Law Review, 67, 14-71.

Nederlands Forensisch Instituut. (2003). Nederlands Forensisch Instituut, jaarverslag 2002. Rijswijk: Nederlands Forensisch Instituut (http://www.forensischinstituut.nl/).

Nijboer, J.F. (1982). Algemene grondslagen van de bewijsbeslissing in het Nederlandse strafproces. Arnhem: Gouda Quint (diss. Leiden).

Nijboer, J.F. (2000). Strafrechtelijk bewijsrecht (4e ed.). Nijmegen: Ars Aequi.

Nijboer, J.F. (2002). Het gekooide denken: Over de rol van discipline binnen feitenonderzoek en bewijs in het recht. Leiden: Universiteit Leiden (oratie Leiden).

Nijboer, J.F. (2003). Forensische expertise (2e ed.). Arnhem: Kluwer.

Nijboer, J.F. (2004a). De omgang met deskundigen in de strafrechtspleging. Trema, 27, 196-205.

Nijboer, J.F. (2004b). De rol van expertise in de rechtspraktijk. Justitiële Verkenningen, 30 (1), 9-19. 
Office of the Inspector General. (1997). The FBI Laboratory: An investigation into laboratory practices and alleged misconduct in explosives-related and other cases. Washington, DC: U.S. Department of Justice, Office of the Inspector General.

O'Hagan, A. (1994). Kendall's advanced theory of statistics, Vol. 2B: Bayesian inference. London: Arnold.

Pearsall, A. (1989). DNA printing: The unexamined witness in criminal trials. California Law Review, 77, 665-703.

Pennington, N. \& R. Hastie. (1986). Evidence evaluation in complex decision making. Journal of Personality and Social Psychology, 51, 242-258.

Pennington, N. \& R. Hastie. (1993). The story model for juror decision making. In: R. Hastie (red.), Inside the jury: The psychology of juror decision making (pp. 192-221). Cambridge: Cambridge University Press.

Penrod, S.D., S.M. Fulero \& B.L. Cutler. (1995). Expert psychological testimony on eyewitness reliability before and after Daubert (Daubert v. Merrell Dow Pharmaceuticals, Inc., 113 S. Ct. 2786 (1993)): The state of the law and the science. Behavioral Sciences and the Law, 13, 229-259.

Peterson, J.L., S. Mihajlovic \& M. Gilliand. (1984). Forensic evidence and the police: The effects of scientific evidence on criminal investigations. Washington DC: U.S. Government printing Office.

Pillai, M.B. (2002). Personal paper is anything but balanced interpretation. British Medical Joumal, 324, 1096.

Poot, C.J. de, R.J. Bokhorst, P.J. van Koppen \& E.R. Muller. (2004). Rechercheportret: Over dilemma's in de opsporing. Alphen aan den Rijn: Kluwer.

Popper, K.R. (1934). Logik der Forschung: Zur Erkenntnistheorie der modernen Naturwissenschaft. Wien: Springer.

Posner, R.A. (1999). An economic approach to the law of evidence. Stanford Law Review, 51, 1477-1546.

Rassin, E. \& P.J. van Koppen. (2002). Het verhoren van kinderen in zedenzaken. In: P.J. van Koppen \& D.J. Hessing \& H. Merckelbach \& H.F.M. Crombag (red.), Het recht van binnen: Psychologie van het recht (pp. 507530). Deventer: Kluwer.

Rassin, E. \& H. Merckelbach. (1999). The potential conflict between clinical 
and judicial decision making heuristics. Behavioral Sciences and the Law, 17, 237-248.

Redmayne, M. (2001). Expert evidence and criminal justice. Oxford: Oxford University Press.

Risinger, D.M. \& M.J. Saks. (2003). A house with no foundation. Issues In Science and Technology, 20, 35-39.

Roberts, L. (1991). Fight erupts over DNA fingerprinting. Science, 254, 17211723.

Robertson, B. \& G.A. Vigneaux. (1995). Intepreting evidence: Evaluating forensic science in the courtroom. Chichester: Wiley.

Rompen, J.C., M.F. Meek \& M.V. van Andel. (2000). A cause célèbre: The socalled Ballpoint Murder. Journal of Forensic Sciences, 45, 1144-1147.

Ruby, C.L. \& J.C. Brigham. (1997). The usefulness of the Criteria-BasedContent Analysis Technique in distinguishing between truthful and fabricated allegations: A critical review. Psychology, Public Policy, and Law, 3, 705-737.

Ruiter, C. de (2000). Voor verbetering vatbaar. De Psycholoog, 35, 423-428 (oratie Universiteit van Amsterdam).

Ruiter, C. de (2004). Forensisch gedragsonderzoek in strafzaken. Justitiële Verkenningen, 30 (1), 50-60.

Saks, M.J. (1994). Implications of the Daubert Test for forensic identification science. Shepard's Expert and Scientific Evidence Quarterly, 1, 427-434.

Saks, M.J. (1998). Merlin and Solomon: Lessons from the law's formative encounters with forensic identification science. Hastings Law Journal, 49, 1069-1141.

Saks, M.J. (2000). The aftermath of Daubert (Daubert v. Merrell Dow Pharmaceuticals, Inc., $113 \mathrm{~S}$. Ct. 2786 (1993)): An evolving jurisprudence of expert evidence. Jurimetrics Joumal, 40, 29-241.

Sappington, A.A. (1990). Recent psychological approaches to the free will versus determinism issue. Psychological Bulletin, 108, 19-29.

Sbraga, T.P. \& W. O'Donohue. (2003). Post hoc reasoning in possible cases of child sexual abuse: Symptoms of inconclusive origins. Clinical Psychology: Science and Practice, 10, 320-334. 
Schoon, G.A.A. \& P.J. van Koppen. (2002). Identificatie door honden. In: P.J. van Koppen \& D.J. Hessing \& H. Merckelbach \& H.F.M. Crombag (red.), Het recht van binnen: Psychologie van het recht (pp. 597-622). Deventer: Kluwer.

Soppe, H.J.G. (1997). Het verhoren van kinderen in zedenzaken. In: P.J. van Koppen \& D.J. Hessing \& H.F.M. Crombag (red.), Het hart van de zaak: Psychologie van het recht (pp. 352-377). Deventer: Gouda Quint.

Stoney, D.A. (1997). Fingerprint identification: B. Scientific status. In: D.L. Faigman \& D.H. Kaye \& M.J. Saks \& J. Sanders (red.), Modern scientific evidence: The law and science of expert testimony (Vol. 2, pp. 55-78). St. Paul, MI: West.

Thompson, W.C. (1997a). Accepting lower standards: The national research council's second report on forensic DNA evidence. Jurimetrics Joumal, 37, 405-424.

Thompson, W.C. (1997b). Forensic DNA evidence. In: B. Black \& P. Lee (red.), Expert evidence: A practitioner's guide to law, science and the FJC manual (pp. 195-266). St. Paul, MN: West.

Thompson, W.C. \& E.L. Schumann. (1987). Interpretation of statistical evidence in criminal trials: The prosecutor's fallacy and the defense attorney's fallacy. Law and Human Behavior, 11, 167-187.

Thompson, W.C., F. Taroni \& C.G.G. Aitken. (2003). How the probability of a false positive affects the value of DNA evidence. Journal of Forensic Sciences, 48, 47-54.

Veer, B.A. van der \& A. Sennef. (1999). Case descriptions. In: M. Malsch \& J.F. Nijboer (red.), Complex cases: Perspectives on the Netherlands criminal justice system (pp. 123-157). Amsterdam: Thela-Thesis.

Verheij, B. (2000). Dialectical argumentation as a heuristic for courtroom decision making. In: P.J. van Koppen \& N.H.M. Roos (red.), Rationality, information and progress in law and psychology (Liber amicorum Hans F.M. Crombag) (pp. 203-226). Maastricht: Maastricht University Press.

Vos, A.F. de (2004). Door statistici veroordeeld? Nederlands Juristenblad, 79. 686-688.

Vrij, A. (2002). Het verhoren van verdachten. In: P.J. van Koppen \& D.J. 
Hessing \& H. Merckelbach \& H.F.M. Crombag (red.), Het recht van binnen: Psychologie van het recht (pp. 699-725). Deventer: Kluwer.

Watkins, S.J. (2000). Convicted by methematical error? British Medical Joumal, 320, 2-3.

White, S., G.A. Strom, G. Santilli \& B.M. Halpin. (1986). Interviewing young sexual abuse victims with anatomically correct dolls. Child Abuse and $\mathrm{Ne}$ glect, 10, 519-529.

Wilson, T.D. (2002). Strangers to ourselves: Discovering the adaptive unconscious. Cambridge, MA: Belknap.

Wolters, G. (2002). Herinneren door getuigen. In: P.J. van Koppen \& D.J. Hessing \& H. Merckelbach \& H.F.M. Crombag (red.), Het recht van binnen: Psychologie van het recht (pp. 397-415). Deventer: Kluwer.

Zeelenberg, A.J. \& W. Simon. (1993). Het identificatieproces van dactyloscopische sporen: Voor dactyloscopen bestaat de doodstraf nog. Den Haag: Vuga. 